\title{
Industrial Production and Capacity Utilization: The 2005 Annual Revision
}

\section{Kimberly Bayard and Charles Gilbert, of the Board's Division of Research and Statistics, prepared this article. Vanessa Haleco provided research assistance.}

On November 7, 2005, the Board of Governors of the Federal Reserve System issued revisions to its index of industrial production (IP) and the related measures of capacity and capacity utilization for the period from January 1972 through September 2005. For this period, both the levels and the rates of change were revised. For years before 1972, the levels, but not the rates of change, were also revised. Overall, the changes to total industrial production were small (figure 1). ${ }^{1}$

Note: Charles Gilbert directed the 2005 revision and, with Kimberly Bayard, David Byrne, Christopher Kurz, Paul Lengermann, Maria Otoo, Dixon Tranum, and Daniel Vine, prepared the revised estimates of industrial production. Norman Morin, John Stevens, and Daniel Vine prepared the revised estimates of capacity and capacity utilization. David Byrne, Carol Corrado, and Aditya Bhave prepared the improved estimates for communications equipment.

1. The production and capacity indexes and the utilization rates referred to in the text and shown in the tables and charts are based on
Besides the revisions to the monthly data for IP and capacity utilization starting in 1972, the comparison base year for all production and capacity indexes was changed: The indexes are now expressed as percentages of output in 2002 instead of 1997. ${ }^{2}$ The rebasing affects all series from their start dates: 1919 for total IP and manufacturing IP, 1948 for manufacturing capacity, and 1967 for total industrial capacity.

Table 1 summarizes the changes to industrial production, capacity, and capacity utilization from 2001 forward. Measured from fourth quarter to fourth quarter, industrial output since 2001 is now reported to have increased a little more overall than reported previously. The contraction in 2001 is now shown to be a bit steeper than it was earlier, and the gains in

Lhe data published in the G.]7 Federal Reserve Statistical Release "Industrial Production and Capacity Utilization" on lisbruary 15, 2006. Statements aboul previously reported estimales refer to the datat published on Ostober 14, 2005.

2. lor comparisons in this artich between the misted and previous indexes, the previous inclexes are implicilly recomputed to hate a base year of 2002 .

1. Industrial production, capacity, and capacity utilization: Total industry, January 1999-January 2006

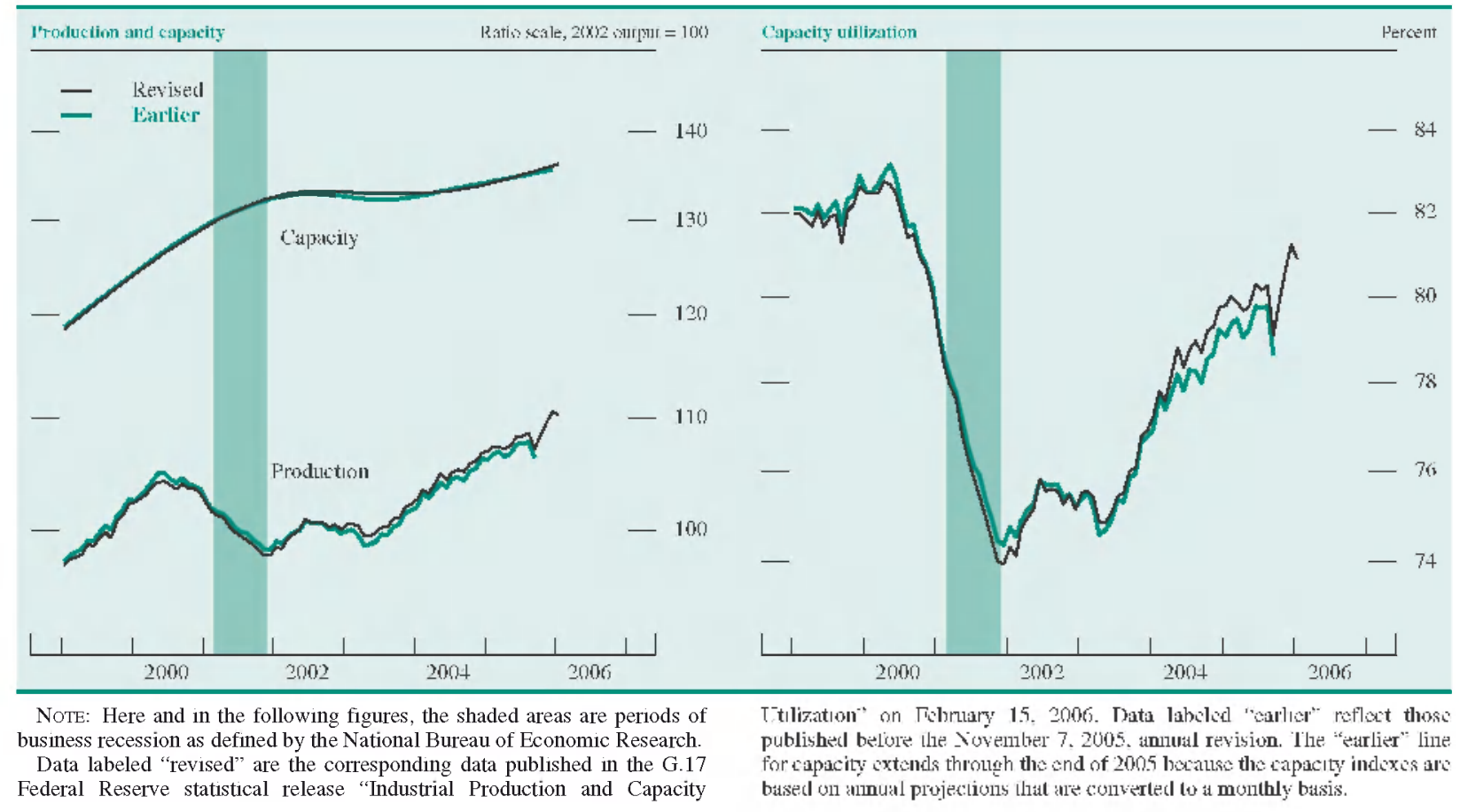


1. Revised rates of change in industrial production and capacity and the revised rates of capacity utilization, 2001-05

\begin{tabular}{|c|c|c|c|c|c|c|c|c|c|c|c|c|c|}
\hline \multirow{2}{*}{ Tlim } & \multirow{2}{*}{$\begin{array}{c}\text { MLmo: } \\
2005 \\
\text { pro- } \\
\text { pirtion }\end{array}$} & \multicolumn{6}{|c|}{$\begin{array}{l}\text { Revised rate } \\
\text { (perwent) }\end{array}$} & \multicolumn{6}{|c|}{ 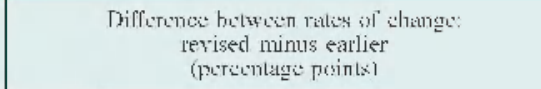 } \\
\hline & & $\begin{array}{c}20 j 1-155 \\
\text { avg. }\end{array}$ & 20101 & 2002 & 20113 & 20194 & 2010.5 & $\begin{array}{c}3001-15 \\
\text { at*⿳亠口冋. }\end{array}$ & 3001 & 20102 & 2013 & 20114 & 2010.5 \\
\hline \multicolumn{14}{|l|}{ Production } \\
\hline Teltal index & 10000 & 1.0 & -5.3 & $2 . .3$ & 1.5 & $4 .{ }^{3}$ & 2.3 & .2 & -2 & .8 & .3 & 0 & .2 \\
\hline 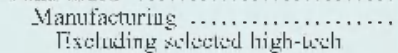 & 8il.8 & 1.2 & -56 & 3.2 & 1.7 & 5.1 & 2.6 & .2 & -.2 & i) & .2 & .1 & .2 \\
\hline 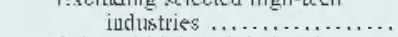 & 76.0 & .5 & -5.2 & 1.9 & .4 & 4.2 & 1.2 & .2 & -3 & 1.2 & .j & i) & i) \\
\hline Selvelied ligigh-liweh industrix & 4.8 & $12 ?$ & -9.8 & 4.8 & 21.1 & 18.4 & 2.5 .2 & 6 & 3 & $-3 . .3$ & 2.4 & -.3 & 101 \\
\hline Miuing and utilities $\ldots \ldots \ldots \ldots \ldots$. & 19.2 & .2 & -3.4 & 2.7 & .6 & .5 & .) & .2 & -.1 & -1 & 1.6 & i) & i) \\
\hline \multicolumn{14}{|l|}{ Caparisy } \\
\hline lotal index & Liliilij & 1.1 & 2.9 & .7 & -.2 & 6 & 1.5 & .1 & .2 & .3 & .6 & -.5 & .4 \\
\hline Yimufituring & 82.9 & 1.1 & 2.8 & .4 & -1 & .5 & 20 & .1 & .3 &..$^{2}$ & (1) & -.6 & 6 \\
\hline $\begin{array}{l}\text { Exthludug selested high-tech } \\
\text { industries }\end{array}$ & 77.4 & .2 & .8 & -.2 & -5 & .1 & 6 & $\therefore$ & .3 & .2 & .1 & 0 & .3 \\
\hline Selected high-tech industries & 5.5 & $14 . \overline{3}$ & 27.8 & $9 . \overline{5}$ & 8.0 & 6.8 & 19.7 & $-i \bar{i}$ & 3 & $1 . \overline{5}$ & -.4 & -66 & $\ddot{5.1}$ \\
\hline Wining and utilitives & 17.1 & 1.5 & 3.1 & 2.3 & 1.3 & 1.2 & -2 & -.1 & 1 &.- .3 & .7 & .2 & -6 \\
\hline \multicolumn{14}{|l|}{ Capacity utilization } \\
\hline Trutial indes & 100.0 & 77.1 & 74.2 & 75.3 & 766 & 79.4 & 798 & .1 & -4 & -.1 & .1 & 6 & .5 \\
\hline 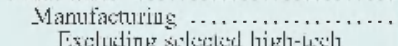 & 82.9 & 75.4 & 72.1 & 73.4 & 74.7 & 78.2 & 78.5 & i) & -.5 & -.1 & .6) & .5 & .3 \\
\hline 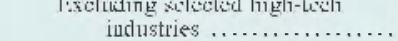 & 77.4 & 76.2 & 73.2 & 74.8 & 75.4 & 78.6 & 78.9 & -.1 & -.6 & .1 & .1 & .1 & -.1 \\
\hline Solvolid liigh-liteh industries & 5.5 & 66.7 & 61.1 & 58.5 & 6.7 & 72.8 & 75.3 & .2 & .3 & $-2 . .3$ & -1.0 & 3.10 & 1.1 \\
\hline Miuing and utilities $\ldots \ldots \ldots \ldots \ldots$. & 17.1 & 86.8 & 87.9 & 87.3 & 86.7 & 86.1 & 86.7 & .7 & .2 & .3 & $1.0 \mathrm{j}$ & .8 & 1.2 \\
\hline
\end{tabular}

2002, 2003, and 2005 are stronger. The increase in output in 2004 is the same as previously reported. ${ }^{3}$

As of the third quarter of 2005 , industrial capacity utilization - the ratio of production to capacity - was 79.8 percent, a little higher than previously stated but 1.2 percentage points below the 1972-2004 average. ${ }^{4}$ For the fourth quarter of 2004, capacity utilization was revised up 0.6 percentage point, to 79.4 percent; upward revisions to the operating rates for manufacturing and mining more than offset a downward revision to the operating rate for utilities. ${ }^{5}$

The revision indicates that industrial capacity increased at a faster rate in 2001, 2002, and 2005 than reported earlier. The rate of change for 2003 was unaltered, and the current estimates for 2004 point to a slower expansion than reported earlier.

The updated measures of production and capacity reflect the incorporation of newly available, more-

3. For 2005, the rates of change are calculated from the fourth quarter of 2004 to the fourth quarter of 2005 , but any comparisons made between the curemt industrial production dala and the prerevision datat are based on annualized rales of change from the fourth quarter of 2004 to the third quarter of 2005.

4. These comparisons use quarterly average data.

5. The fourth quarter of 2004 is the most recent quarter with at ailable survey data on capacity ulilization. comprehensive source data and improved methods for compiling a few series. The new annual source data are generally for 2003 and 2004, and the modified methods affected indexes largely from 1997 forward.

The statistical revisions to the IP index were derived principally from the inclusion of information contained in annual reports issued by the U.S. Census Bureau-namely, the 2003 Annual Survey of Manufactures, the revised 2002 Census of Manufactures, and selected 2004 Current Industrial Reports. New government source data included annual data on minerals for 2003 and 2004 from the U.S. Geological Survey (USGS) and updated deflators from the Bureau of Economic Analysis. Also, the new monthly production estimates reflect updated seasonal factors and include monthly source data that became available, or were revised, after the closing of the regular four-month reporting window.

The capacity indexes and capacity utilization rates incorporate the revised production indexes; results from the Census Bureau's 2004 Survey of Plant Capacity for the fourth quarter of the year; and newly available data on industrial capacity from the USGS, the Energy Information Agency of the Department of Energy, and other organizations. 
2. Industrial production: Market groups, January 1989-January 2006

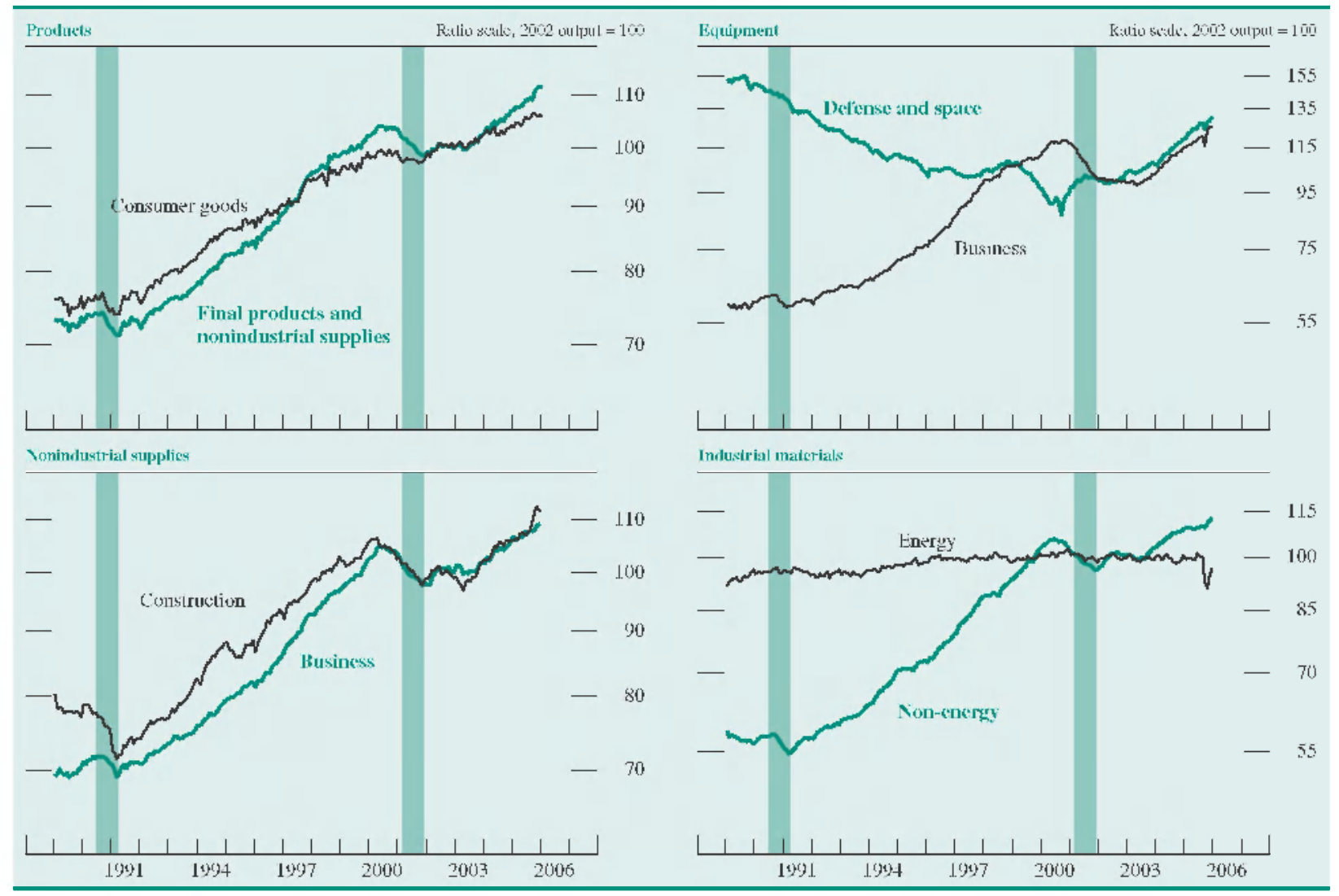

\section{RESULTS OF THE REVISION}

For the third quarter of 2005 , total industrial production was reported to be 108.0 percent of output in 2002 , and capacity stood at 135.3 percent of output in 2002. Both indexes are higher than reported previously. The capacity utilization rate for total industry, at 79.8 percent, was slightly higher than earlier reports indicated. Results of the revision can be found in the appendix tables. ${ }^{6}$

6. Table A.I shows the resised data for total industrial production, and table $A .2$ shows the revised data tor capacity and capacity uliliyalion for Lotal industry. Tables A.3 and A.4 show the revised rates of change (fourth quarter to fourth quarter) of industrial production for market groups. industry groups. special agoregates. and selected detail for the years 200] through 2005. Table A.5 shows the revised rates of change of annual industrial production indexes for market and industry groups for the years 2001 through 2005. Tables A.6 and A.7 show the revised ligures for eapacily and capacily ulilizalion. Tables A.3, A.4. A.5, and A.6 also show the difference betwen the ruised and arlicr rates of change. lable $A .7$ shows the ditterence between the revised and previous rates of capacity utilization for the final cquarter of the year. Table A. 8 shows the amual proportions of market wroups and inclustry groups in total IT?

\section{Industrial Production}

The revision indicated that the overall path of industrial production was much the same as stated earlier. The most significant features of this revision-the incorporation of the 2003 Annual Survey of Manufactures and of the revision to the 2002 Census of Manufactures-had little effect on the top-line estimates. From 1992 through 2000, total IP increased at an average annual rate of 4.7 percent. The index declined 3.5 percent in 2001. After the trough, IP registered moderate gains in 2002, 2003, and 2005 and advanced strongly in 2004 (figure 1).

\section{Market Groups}

Among major market groups (figure 2 and table A.3), the revision shows little change compared with previous estimates in production for final products and nonindustrial supplies for recent years. This index declined in 2001, posted moderate gains in 2002 and 2003, and increased more rapidly in 2004 and 2005 
(measured from the fourth quarter of the preceding year to the fourth quarter of the year indicated). Overall, the revisions to consumer goods were small for recent years, and the index still shows a general climb since having dropped back in 2001. The revisions to most of the components of consumer goods were small; however, new data yielded a sizable downward revision to home electronics for 2003, which resulted in less of an increase than stated earlier.

The production of business equipment is now reported to have been somewhat weaker, on balance, in the 2001-05 period than estimated earlier; a downward revision to the index for information processing equipment is largely responsible for the lower 2003 estimate. The output of business equipment declined in 2001 and 2002 but has risen since then. The production of defense and space equipment has increased in recent years, particularly in 2004 and 2005; however, the revision indicates smaller gains in 2002 and 2005 than stated previously and a larger gain in $2004 .{ }^{7}$ The indexes for construction supplies and business supplies were revised little for recent years; output in these two market groups dropped in 2001 but has risen in each year since. From 2002 through 2004, the gains in the output of materials were revised up about 0.7 percentage point per year; 2005 had a smaller upward revision, and 2001 had a downward revision of $1 / 2$ percentage point. Production of materials has advanced in every year from 2002 on; the largest increases were in 2002 and 2004. The production of non-energy materials was revised up, overall, in the 2001-05 period. Within this group, the index for durable materials was revised up a bit. The index for nondurable materials revised up in 2002 and was little changed, on balance, in subsequent years. The output of energy materials was nearly unchanged for 2001-03; the rate of change was revised up a bit in 2004 and down a similar amount in 2005 .

\section{Industry Groups}

Relative to earlier reports, the current estimates for manufacturing IP indicate a slightly steeper upward trajectory for 2002 through 2005 (table A.3). Like the revisions to total industrial production, the current estimates for manufacturing IP show a marginally larger decline in 2001 and a faster increase in 2002.

7. For 2005 , the thircl cyuarler of 2005 was used to calculate the extent of the revisions.
The increases in 2003, 2004, and 2005 were slightly greater than earlier estimates.

Compared with the previous estimates, the revision to durable manufacturing shows a larger rate of decline in 2001 and a more rapid rate of increase since then. The overall contour of this index shows solid gains for the past few years-more than 5 percent per year, on average, from 2002 forward. All major durable goods industries posted gains in 2004, and many showed continued strength in 2005. The only major industries with notable decreases in production in 2005 were primary metals and furniture and related products.

Overall, the index for nondurable manufacturing was little changed from earlier estimates. The output of nondurables declined markedly in 2001 and advanced strongly in 2004; the swings in other recent years were less pronounced. On balance, the output indexes for textile and product mills and for apparel and leather have registered sharp declines in recent years, whereas the indexes for food, beverage, and tobacco products; chemicals; and plastics and rubber products all posted gains.

The revision indicated lower output in recent years for the industries that have historically been defined as manufacturing (namely, publishing and logging) but that are classified elsewhere under the North American Industry Classification System (NAICS). In 2003 and 2004, the rates of change are now, on average, about 2 percentage points lower than previously published.

\section{Special Aggregates}

A number of special industrial production aggregates are published to help users understand changes in the industrial sector (table A.4). The high-technology industries are important contributors to growth in the manufacturing sector (figures 3 and 4). The revision shows little change to the aggregate for selected high-technology industries - computers and peripheral equipment, communications equipment, and semiconductors and related electronic components. The small revisions to the aggregate, however, mask somewhat larger revisions to each of its lower-level industries. The production of computers and peripheral equipment is now estimated to have declined in 2002, rather than to have increased, and to have risen less in 2003 and 2004 than was reported earlier; the output gain in 2005 is nearly the same as estimated earlier. For communications equipment, the revision shows a steeper drop in production in 2002 and a more moderate recovery in 2003 than previously 
3. Industrial production: Manufacturing, and manufacturing excluding selected high-technology industries, January 1989-January 2006

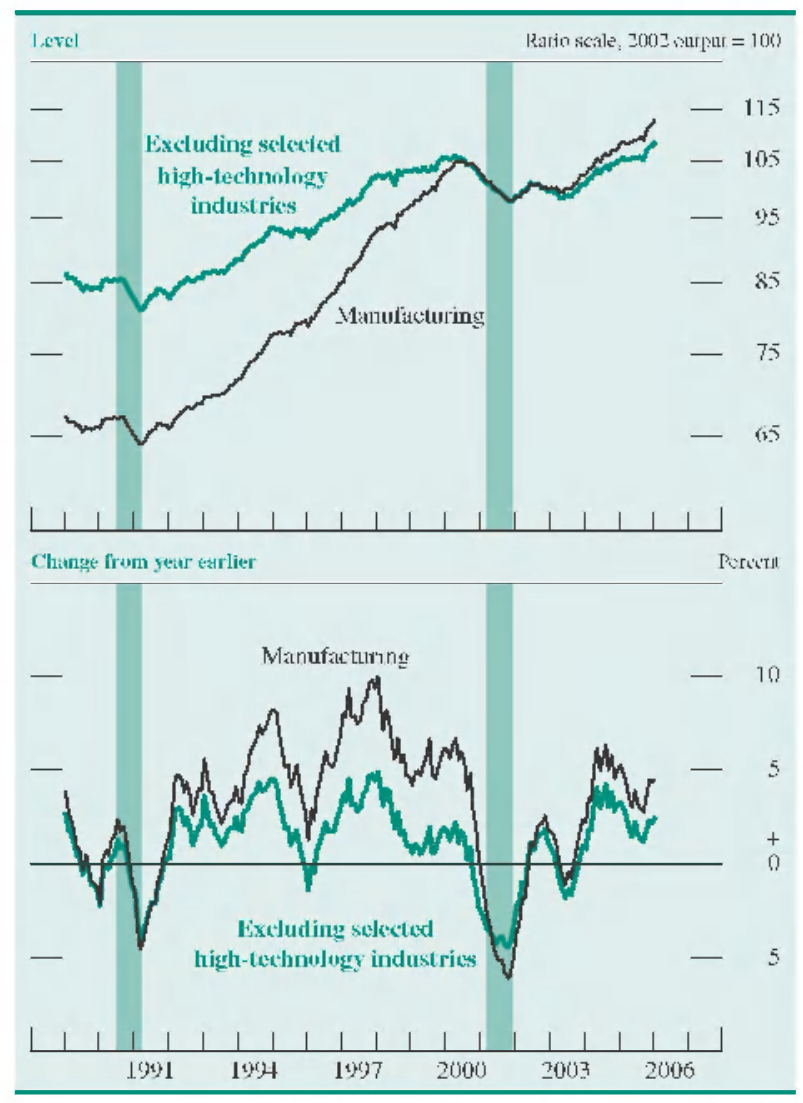

Note: Manufacturing comprises North American Industry Classification System (NAICS) manufacturing industries (sector 31-33) plus the logging industry and the newspaper, periodical, book, and directory publishing industries. Logging and publishing are classified elsewhere in NAICS (under agriculture and information respectively), but historically they were considered to be manufacturing industries and were included in the industrial sector under the Standard Industrial Classification (SIC) system. In December 2002 the Federal Reserve reclassified all its industrial output data from the SIC system to NAICS.

The selected high-technology industries are semiconductors and related electronic components (NAICS 334412-9), computers and peripheral equipment (NAICS 3341), and communications equipment (NAICS 3342).

stated; output is now estimated to have risen more rapidly in 2004 and 2005 . The index for semiconductors has risen rapidly since a small decline in 2001. Compared with previous estimates, the revision to semiconductors shows a slower increase in 2004 but a more rapid increase in 2003.

The output gain for motor vehicles and parts is now reported to have been stronger in 2002 and 2005-by about 1 percentage point-than was reported earlier. The estimates for other recent years are similar to previous reports.

\section{Capacity}

The revision did not change the overall contour of manufacturing capacity. Capacity still accelerates
4. Industrial production: Selected high-technology industries, January 1999-January 2006

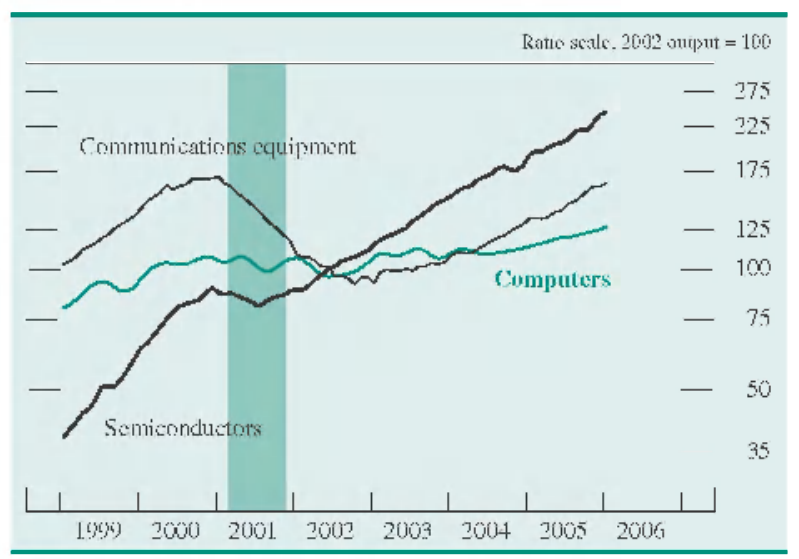

NoTE: Refer to general note in chart 3 .

rapidly in the second half of the $1990 \mathrm{~s}$, then decelerates through 2004 (with a small decline in 2003), and picks up moderately in 2005 (figure 1). The expansion in 2004 is now reported to have been less than estimated earlier, and the increase in 2005 is somewhat stronger (table A.6). Among selected hightechnology industries, the revision suggests a slower expansion of capacity in 2003 and 2004 than reported earlier; however, for 2005, high-technology capacity expanded more rapidly than stated previously20.8 percent.

Capacity in mining is now estimated to have decreased in each of the past four years and has declined, on balance, more than previously estimated. In contrast, capacity at electric and gas utilities accelerated sharply from 2001 to 2004 and flattened out in 2005; the current estimates for 2005 are lower than previously reported.

By stage of process, capacity in the crude stage, which has contracted since 2001, is now estimated to have been somewhat weaker, on balance, in the 2001-05 period than reported earlier. Relative to previous reports, the capacity index for the primary and semifinished stages increased more in 2001, 2002, and 2005; declined less in 2003; and increased less in 2004. Among finished goods producers, capacity expanded throughout the 2001-05 period. Relative to earlier reports, the revised estimates show more acceleration in 2002,2004, and 2005 and a little less in 2001; the estimates for 2003 were unrevised.

\section{Capacity Utilization}

Capacity utilization for total industry was revised up in recent years, but the revisions were relatively small; for the third quarter of 2005 , utilization stood 
at 79.8 percent, a rate 0.5 percentage point higher than previous estimates suggested but 1.2 percentage points below its long-term (1972-2004) average (table A.7).

The factory operating rate reached 78.5 percent in the third quarter of 2005 after an upwardly revised reading of 78.2 percent in the fourth quarter of 2004 and an unrevised 74.7 percent in the fourth quarter of 2003. Within manufacturing, the current revision places the overall utilization rates in recent years for durable goods manufacturers somewhat higher than previously stated, especially in the fourth quarter of 2004 and the third quarter of 2005 . The utilization rates for manufacturers of nondurables were little changed from earlier estimates. Capacity utilization in the other (non-NAICS) manufacturing industries is now lower than previously reported, and the recent increases are smaller than those stated earlier.

Among selected high-technology industries, utilization is now reported to have been lower in the fourth quarters of 2002 and 2003 but higher in the fourth quarter of 2004 and the third quarter of 2005 (figures 5 and 6). For 2002, a downward revision to the utilization rate for semiconductors and related electronic components accounts for most of the lower estimate. For 2003 , the downward revision is largely attributable to lower utilization in the communications equipment industry. For 2004 and 2005, higher utilization rates for producers of semiconductors and related electronic components account for much of the upward revisions. Excluding these hightechnology industries, capacity utilization for manufacturing is little changed.

Capacity utilization in mining was revised up, to 88.3 in the fourth quarter of 2004 and to 86.1 in the third quarter of 2005 ; these estimates are, respec-

5. Capacity utilization: Selected high-technology industries and manufacturing excluding selected high-technology industries, January 1989-January 2006

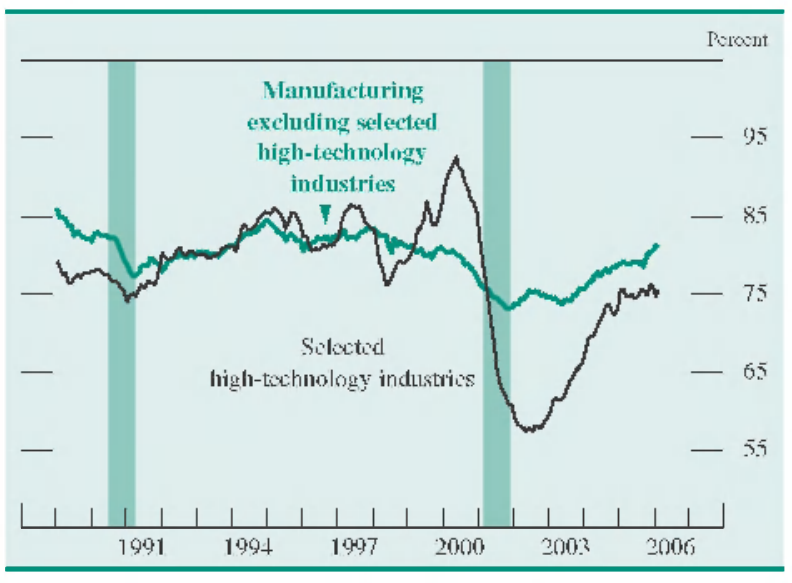

6. Capacity utilization: Selected high-technology industries, January 1996-January 2006

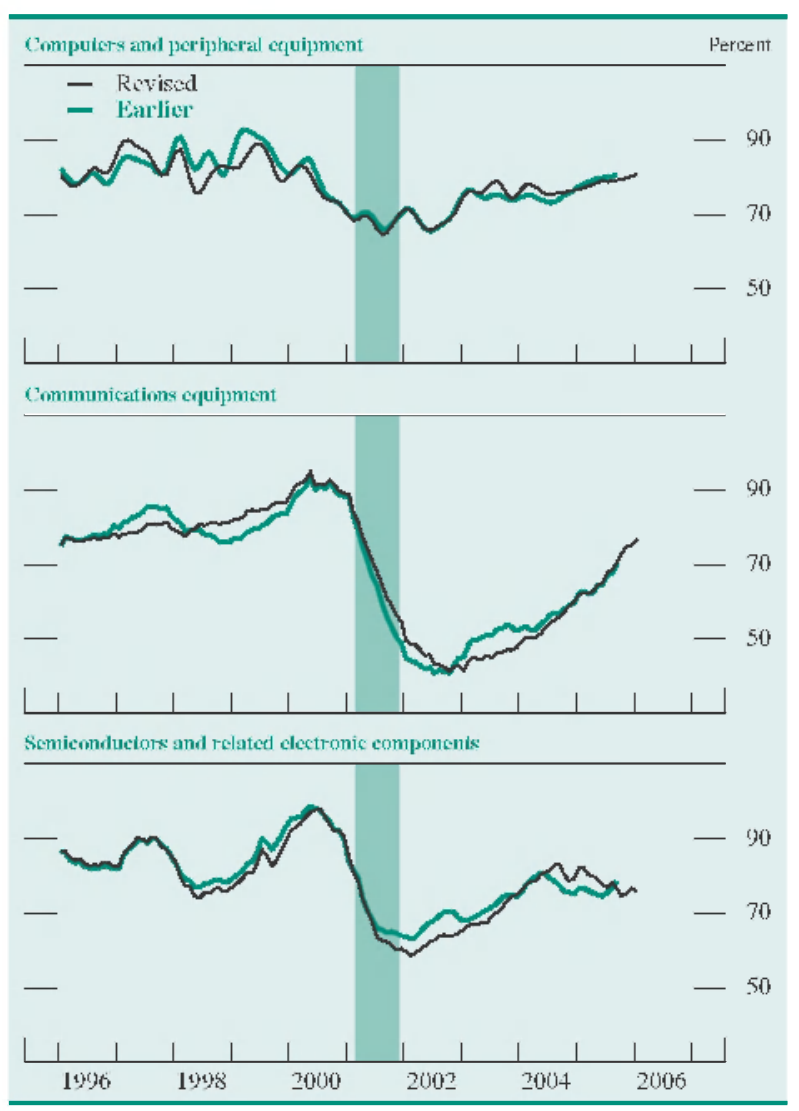

tively, about 1 percentage point above and below the index's long-term average. Improved capacity estimates of support activities for mining accounted for much of the recent revisions. The utilization rate for electric and gas utilities in the third quarter of 2005 was little changed by the revision and stood at 88.1 percent, a rate 1.3 percentage points above its long-term average.

\section{TECHNICAL ASPECTS OF THE REVISION}

The revision incorporates updated comprehensive annual data and revised monthly source data used in the estimation of production, capacity, and utilization. As noted earlier, this revision includes information drawn from the 2003 Annual Survey of Manufactures. This revision also incorporates the 2004 Survey of Plant Capacity, other annual industry reports on output and capacity, recent information on prices, and revised monthly source data on physical products and on labor inputs. Along with the individual production series and seasonal factors, the annual value-added weights used in aggregating the 
indexes to market and industry groups were also updated.

\section{Changes to Benchmark Indexes}

The benchmark indexes for manufacturing-defined for each six-digit NAICS industry as nominal gross output divided by a price index-were updated to include new information from the 2003 Annual Survey of Manufactures (ASM) and revisions to the estimates from the 2002 Census of Manufactures.

The benchmark indexes for most industries incorporated updated price indexes from the industry output program of the Bureau of Economic Analysis (BEA). One exception is the benchmark index for semiconductor manufacturing, which comprises five subindustry indexes (figure 7). The price indexes for these subindustry indexes are constructed from information issued by trade associations, private research companies, company reports, and producer price indexes from the U.S. Bureau of Labor Statistics. ${ }^{\text {s }}$ Because the overall benchmark price index for semiconductor manufacturing falls faster than the BEA index, the Federal Reserve's measure of real output in this industry rises faster than the comparable BEA measure. If the BEA price index were used in place

8. Carol Cortado (2003), "Tndustrial Production and Capacily Itilization: The 2002 Historical and Annual Revision," Fetieral Reserve Bufletin. vol. 89 (April), pp. 151-76.

7. Annual price index: Semiconductors, 1997-2004

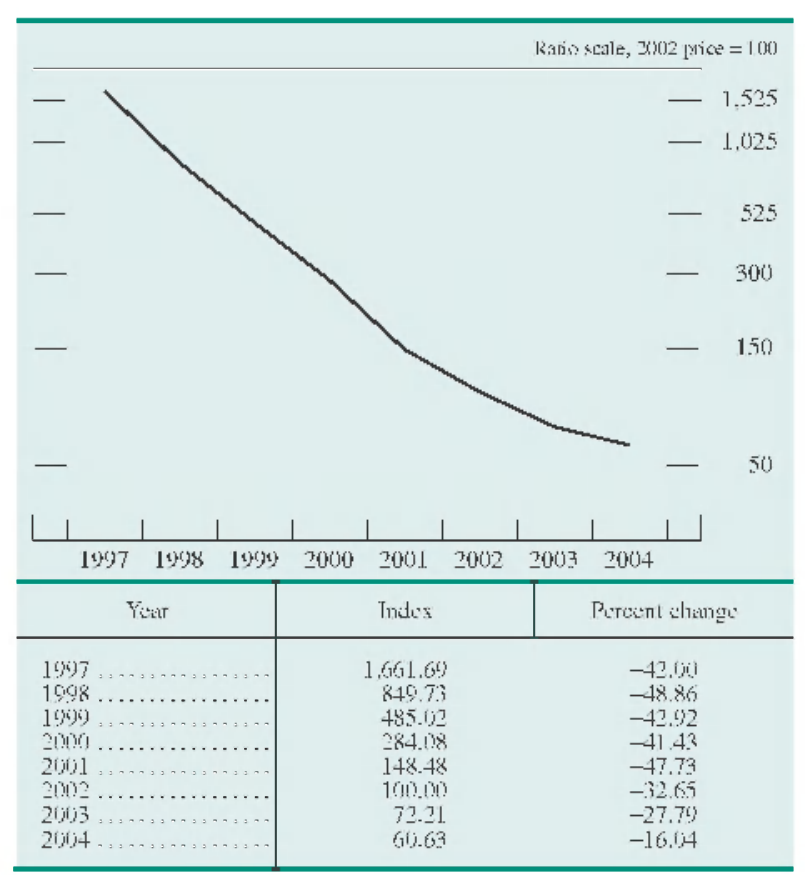

of the Federal Reserve's index, the rate of change for the output of semiconductors would have been 33 percentage points lower per year, on average, from 1997 to 2003.

The price indexes used for most components of communications equipment are also constructed by the Federal Reserve and were updated in this revision. Price and production indexes for networking equipment (routers, switches, and hubs) are discussed later. Among non-networking equipment, industry and government sources on prices for central office equipment, fiber-optic equipment, PBX (private branch exchange) equipment, consumer telecommunications equipment, and wireless infrastructure equipment were used to extend previous work through 2004.

Another change to the benchmark indexes for 2003 involved the recalculation of nominal gross output. Before the 2004 annual revision, nominal gross output for an industry was calculated as the cost of materials plus value added. In the 2004 revision, the benchmark index from 1997 to 2002 was instead calculated with gross output defined as the traditional figure less the cost of resold goods (those goods purchased by a manufacturer and then resold without any material transformation). The 2003 ASM, however, did not include detailed data for the cost of resold goods; in this revision, the nominal gross output used to compute the changes in the benchmark indexes for 2003 was calculated with the traditional method ${ }^{10}$

The 2003 ASM also featured a reduction in its industry detail. Previous ASMs reported results for every six-digit NAICS industry (473 in manufacturing under the 2002 NAICS). For 2003, however, the reports combined 239 of those six-digit industries into 88 higher-level industry aggregates. The benchmark indexes for manufacturing IP are calculated from gross output for six-digit industries and then aggregated to the IP industry level (210 industries, each one comprising one or more six-digit NAICS industries) using proportions based on value added. To maintain benchmark references that were consistent over time, the Federal Reserve imputed estimates of gross output and value added for those six-digit industries that were dropped from the ASM. For each unreported industry, the imputations were based on values for the aggregate industry that contained it and the shares of the unreported industry in the aggregate in 2002 .

\footnotetext{
9. Corrado. "Industrial Production and Capacity litization," p. 159 .

10. The amnutal changes in the benchmark inclexes between 1997 and 2002 comlinued to be calculated as they were in the 2004 revision.
} 
The loss of the detail in the ASM probably had only a small effect on the IP industry benchmarks. All but eight of the IP industries are made up entirely of industries or industry combinations that were reported in the ASM. Because the other eight industries, which constitute about 3 percent of total IP, are all six-digit NAICS industries, any effects of the imputation of nominal gross output mostly cancel out at the five-digit NAICS industry level.

\section{Changes to Individual Production Series}

With this revision, the monthly production indicators for some series have changed. The source data for production indexes for the following twenty industries, which constituted 10.9 percent of IP in 2004, have been changed from electric power use to production-worker hours for 1997 to the present:

1. fruit and vegetable preserving and specialty food (NAICS 3114)

2. other food (31193-9)

3. leather and hide tanning and finishing (3161)

4. printing (32311)

5. soap, cleaning compound, and toilet preparations (3256)

6. other chemical product and preparations (3259)

7. rubber and plastics hoses and belting (32622)

8. other rubber products (32629)

9. other pressed and blown glass and glass-ware (327212)

10. glass product made of purchased glass (327215)

11. lime (32741)

12. other nonmetallic mineral products (3279)

13. ferrous metal foundries (33151)

14. hardware (3325)

15. machine shops; turned product; and screws, nuts, and bolts (3327)

16. air purification equipment, fans, and blowers $(333411,2)$

17. electric lighting equipment (3351)

18. electrical equipment (3353)

19. other electrical equipment $(33593,9)$

20. office furniture (including fixtures) (3372)

The decision to switch the monthly indicators for these series resulted from deterioration in the sample of electric utilities that report power use for these industries. The IP indexes no longer contain any series that are based on electric power use as their monthly indicator for the period 1997 to the present.

The IP indexes based on product data usually reflect measures of production, but some have been based on manufacturers' shipments (the implicit assumption being that the factory inventories do not change). In this revision, the procedure that was introduced in the 2004 annual revision for estimating inventories of the machine tool industry was expanded to the following twenty-one industries (with a total weight in IP of 6.6 percent in 2004) for which shipments are the high-frequency indicator:

1. corn syrup and starch (NAICS 311221 pt.)

2. reconstituted wood products (321219)

3. paperboard containers (32221)

4. pharmaceutical preparations (325412)

5. cement (32731)

6. aluminum foundries $(331521,4)$

7. metal cans, boxes, and other metal containers (light gauge) (33243)

8. burners and other parts (333414 pt.)

9. boilers, heaters, and furnaces (333414 pt.)

10. warm air furnaces (333415 pt.)

11. electron tubes (334411)

12. electric housewares and household fans (335211)

13. household vacuum cleaners (335212)

14. electric water heaters ( $335228 \mathrm{pt}$.

15. gas water heaters ( $335228 \mathrm{pt}$.)

16. storage batteries (335911)

17. truck trailers (336212)

18. motor homes (336213)

19. travel trailers and campers (336214)

20. mattresses (33791)

21. book publishers (51113)

The model underlying the estimates of inventories assumes that manufacturers target a specific inventory-sales ratio. In response to surprises in demand, manufacturers are assumed to adjust production plans to partially accommodate the surprise in the same period, and the remainder of the accommodation takes place in subsequent periods. Figure 8 illustrates the high and low frequency effects of the model-based inventory adjustment on the shipments indicators. As a representative example, seasonally adjusted shipments of cement are shown as the thick green line in the top panel. The shipments indicator adjusted for inventory change-the new production indicator shown as the thin black line - has the same basic contour as shipments, with some of the extreme swings tempered. Similarly, shipments of truck trailers, with and without the model-based inventory adjustment, are shown in the bottom panel. From the fourth quarter of 2000 through mid-2002, the new production indicator is lower than shipments as manufacturers try to keep their inventories in line with slumping demand. 
8. Estimated production and shipments: Cement and truck trailers, January 1999-December 2002

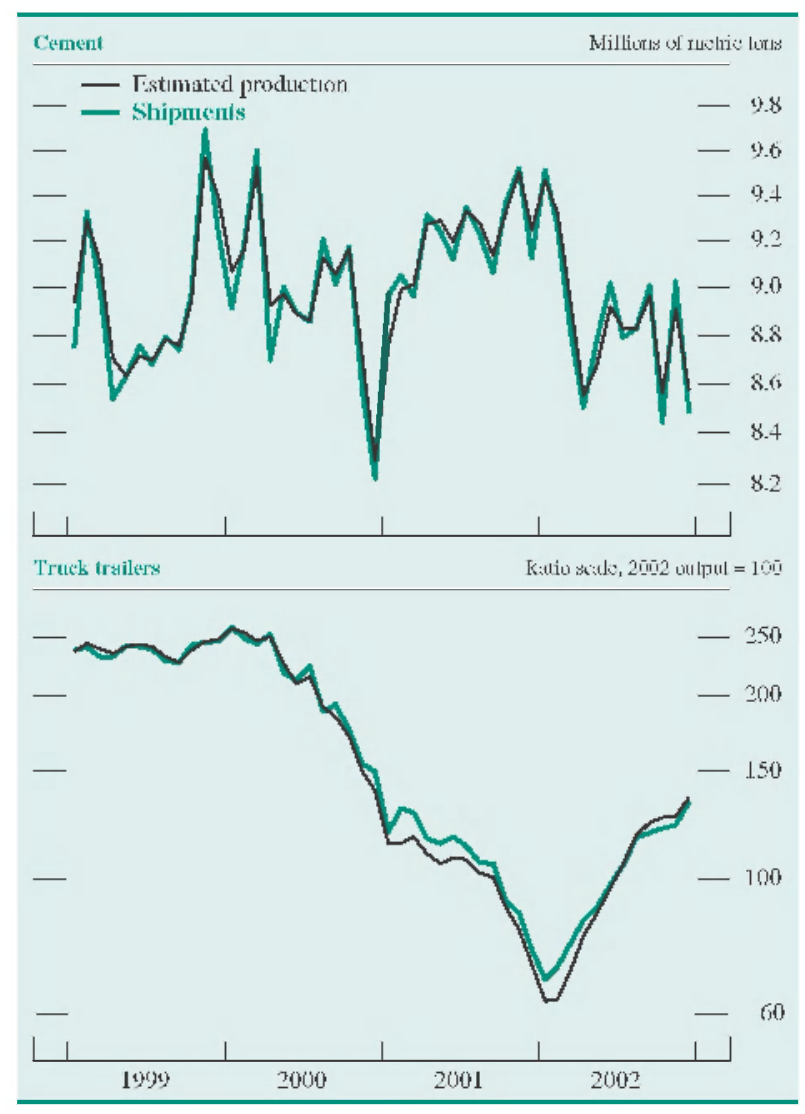

NoTE: Estimated production measures for cement and truck trailers are calculated from shipments adjusted for model-based changes in inventory. Truck trailer data comprise three categories: trailers, containers, and chassis. Shipments of each category are weighted by relative prices and summed; the sum is then indexed.

This revision also incorporated new indicators based on product shipments for four industries. Previously, these industries were estimated from production-worker hours. A model-based estimate of the change in inventories is added to the index derived from shipments to compute a production index for the following four industries:

1. semiconductor manufacturing equipment (NAICS 333295)

2. bare printed circuit boards (334412)

3. printed circuit assemblies (334418)

4. boats (336612)

The total number of individual output indexes that make up industrial production remains at 300 for the period from 1992 forward.

With this revision, the monthly indicator for semiconductor manufacturing equipment (NAICS 333295) from 1992 and forward was derived from data on billings for front-end semiconductor equip- ment from Semiconductor Equipment and Materials International, an industry association; the billings data are deflated by the producer price index for the industry. The indicators for bare printed circuit boards (NAICS 334412) and for printed circuit assemblies (NAICS 334418) are now constructed from a weighted average of shipment indexes of flexible and rigid circuit boards that is deflated by a producer price index. ${ }^{11}$ The output indicator for boats (NAICS 336612) is derived from data from the National Marine Manufacturers Association for the period from 2002 forward; a Fisher quantity index is computed from unit shipments and values for the following eleven types of watercraft:

1. cruisers

2. skiboats

3. inflatables

4. fiberglass outboard boats

5. aluminum outboard boats

6. total sterndrive boats

7. canoes

8. personal watercraft

9. jet drive boats

10. boat trailers

11. kayaks

The new product-based production indexes constituted 1.1 percent of IP in 2004. Table 2 summarizes the type of data (measured as a percentage of value added in 2004) available in each month of the fourmonth IP publication window. The first estimate of output for a month is preliminary and is subject to revision in each of the subsequent three months as new source data become available. By the third revision (the fourth month of estimate), the productbased content of IP is 51.8 percent.

The revision incorporated refined methods for a few series. The production indicator for boilers, heaters, and furnaces (NAICS 333414 pt.) is now based

11. The shipments indexes are from IPC, an association of betronics manulacturers that emphasises the importance of printed circuit boards.

2. Proportion of industrial production data by type available in reporting window, 2004

Percentage of value added

\begin{tabular}{|c|c|c|c|c|}
\hline \multirow{2}{*}{ 'Type of data } & \multicolumn{4}{|c|}{ Month of estimate } \\
\hline & $1: \mathrm{LL}$ & $2 \pi d$ & $3 \mathrm{rd}$ & 4Llı \\
\hline Product-based & 24.8 & 40.4 & 50.7 & 51.8 \\
\hline Presduction-workur hisum. & 449 & 449 & 440 & 44.9 \\
\hline Tistal atrailalsle ........... & 60.7 & 8.3 & 05.6 & 96.7 \\
\hline Federal Reserve estimates. & $30 j .3$ & 14.7 & 4.4 & 3.3 \\
\hline
\end{tabular}


on the quarterly output of boilers (data from the Gas Appliance Manufacturers Association). The data for heaters and furnaces that were previously used to construct the index are no longer available.

The production indicator for machine tools (NAICS 333512, 3) is computed based on a Fisher index of quarterly shipments data from the Census Bureau's Current Industrial Report on metalworking machinery (MQ333W). The report has nominal shipments and unit shipments for numerous categories of machine tools. Previously, the implicit unit values from the report were used as the deflators in the Fisher index calculation. Because the recent data for some of these unit values were highly volatile, a heterogeneity problem in the categories may exist. In this revision, the unit values were replaced by producer price indexes in the Fisher index calculation for the following categories of machine tools: lathes; grinding, polishing, buffing, honing, and lapping machines; machining centers; miscellaneous metal cutting machines valued at more than $\$ 3,025$; punching, shearing, bending, and forming machines; presses valued at more than $\$ 3,025$; and miscellaneous metal forming machines. The following categories still use unit values as deflators: gear cutting machines, milling machines, miscellaneous metal cutting machines valued at less than $\$ 3,025$, and presses valued at less than $\$ 3,025$.

The procedure for estimating the index for civilian aircraft was changed to better capture the occasional severe disruptions to production that result from labor actions. Civilian aircraft production is estimated from data on deliveries of large commercial aircraft (which account for most of the total value of commercial aircraft produced in the United States) and data on production-worker hours for the aircraft assembly industry (NAICS 336411). Every large plane completed in a month is the result of production activity in that month and in a number of earlier months. A preliminary estimate of production is made by assuming that the production embodied in a plane occurred in the month it was delivered and in the nine previous months, with the progress toward completion higher in the last few months before the plane is completed. Previously, the preliminary estimate of output for a period was derived entirely from the delivery levels or scheduled deliveries for planes in subsequent periods. With this revision, the preliminary estimate of output also assumes that the amount of progress that occurred in any one month is dependent on the relative production-worker hours in that month. The implicit productivity series from the preliminary estimates is smoothed and then applied to the productionworker hour series to determine the estimate of the production indicator for IP. A correction factor to align this indicator with the benchmark index is then applied.

\section{Networking Equipment}

The Federal Reserve updated estimates for communications equipment manufacturing (NAICS 3342) from $2001 \mathrm{on}$. The 2000 revision introduced a new IP series for the production of networking equipment (routers, switches, and hubs). ${ }^{12}$ The series is not published in the monthly statistical release, but it is included in the broader IP aggregate for communications equipment and updated on an ongoing basis. Table 3 reports the overall price index for communications equipment manufacturing, the price index for networking equipment and service provider routers, and the price index for all other communications equipment.

Price indexes were constructed for all types of networking equipment from detailed data available from Gartner and from the Telecommunications Industry Association (TIA). Estimates of the annual value of U.S. production by equipment type were developed using information from Current Industrial Reports issued by the U.S. Census Bureau and from consultation with industry analysts.

As usual, the annual revision incorporated source data on networking equipment and service provider routers. In addition to detailed information on routers

12. Carol Corrado (2001). "Industrial Production and Capacity Titilization: The 2000 Annual Reyision," Feteresl Reserve Bulletin, fol. 87 (March), pp. 132-48. The improvements to inclustrial production ontlined in Corrado (2001) whe based on rescarch documented by Mark T)oms and Chris Forman (2005), "Prices For T ocal Area Network Fquipmenl," Infonmation Eromomiss and Policy, fol. 17 (July), pp. 36.5-88.

3. Price indexes for communications equipment manufacturing, 1997-2004

2002 price $=100$

\begin{tabular}{|c|c|c|c|}
\hline Year & lotal & $\begin{array}{l}\text { T.usal arcia } \\
\text { network } \\
\text { equipment } \\
\text { and service } \\
\text { provider } \\
\text { risuluts }\end{array}$ & $\begin{array}{c}\text { Othar } \\
\text { communications } \\
\text { cquipment }\end{array}$ \\
\hline $1907 \ldots \ldots$ & 1578 & 3104 & 134.8 \\
\hline $1908 \ldots$ & 142.5 & 223.9 & 128.8 \\
\hline 1909 & 130,6 & 183.3 & 119.2 \\
\hline zom & 1199 & 1630 & 111.0 \\
\hline $2 i 1101 \ldots \ldots \ldots \ldots \ldots \ldots$ & 109.6 & 128.2 & 1015.5 \\
\hline$\ldots \ldots \ldots \ldots$ & 1000 & 1000 & 1000 \\
\hline (1, & 93.8 & 75.2 & 97.4 \\
\hline 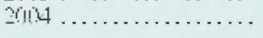 & 868 & 57.19 & 95.5 \\
\hline \multicolumn{4}{|l|}{ MFMo } \\
\hline $\begin{array}{l}\text { Average perceut thange. } \\
\text { livy?-30i4t ....... }\end{array}$ & -8.2 & -21.5 & -4.8 \\
\hline
\end{tabular}


9. Quarterly price indexes: Networking equipment, 2001-04

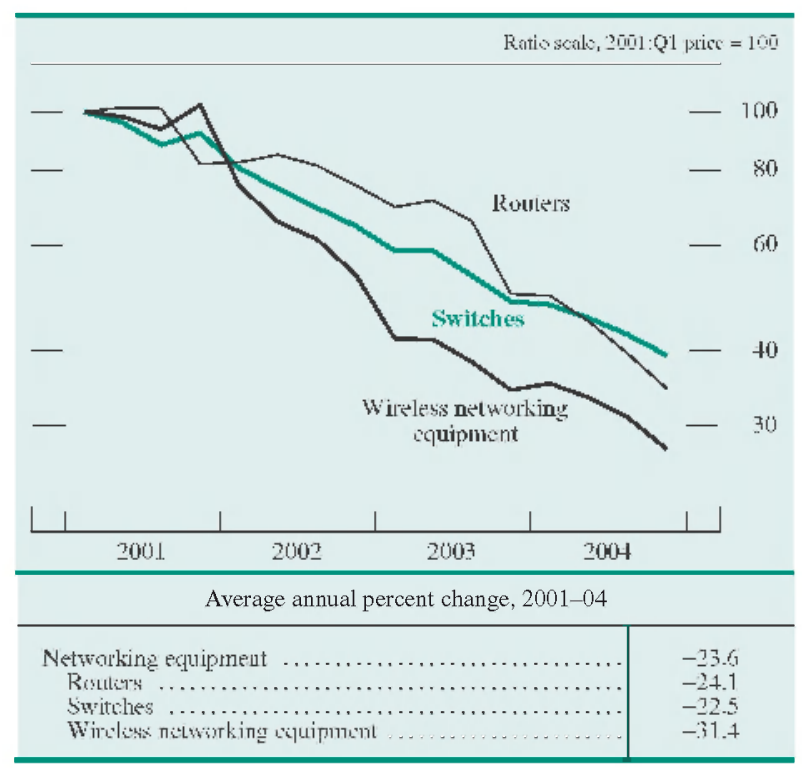

and switches, this year's estimates include new data on wireless networking equipment from Gartner starting in 2001. Products covered include networking switches and controllers, add-on adapters for wireless networking, and wireless access points. Figure 9 shows quarterly price indexes for routers, switches, and wireless networking equipment.

\section{Other Communications Equipment}

The Federal Reserve also updated price and quantity indexes for other types of communications equipment using detailed information found in reports from Gartner and the TIA. The types of equipment covered included fiber-optic equipment, PBX equipment, voice processing equipment, and network access systems.

The price index for fiber-optic equipment, introduced with the 2002 IP revision, was extended this year ${ }^{1.3}$ Information from Gartner on five classes of synchronous optical network (SONET) equipment and three types of digital cross-connect equipment were used to create price indexes for these products. During the 2000-04 period, prices for SONET equipment fell 11 percent and prices for digital crossconnect equipment fell 5 percent. These types of

13. The price indexes for communications squipment introduced in the 2002 revision were based on work described in Mark Joms (2005), "Communications F.quipment: What Has Happened to Prices?' in Carol Corrado, John IIaltiwanger, and Danicl Sichol. cds., Measuting Captat in the New Lconomy, National Burau of Liconomic Research Studies in Income and Wealth (Chicago, TIniłersity of Chicatyo Press), pp. 323-62. equipment account for about two-thirds of worldwide sales of fiber-optic equipment. Because data on prices of wave division multiplex (WDM) equipment were not available this year, the price index for SONET equipment was applied to WDM equipment (access multiplexers are covered under access systems).

PBX equipment was an area of particular focus in this revision because of the ongoing transition away from circuit-switched PBX equipment and toward equipment based on the internet protocol (IP-PBX equipment), which handles voice-over-IP activity. Data on prices and quantities from Gartner for sixteen types of equipment were used to extend this index. Figure 10 shows price indexes for IP-PBX equipment, circuit-switched PBX equipment, and PBX systems that use intermediate technologies. Prices for IP-PBX equipment fell, on average, 5.8 percent per year from 1999 to 2004, somewhat faster than the average of nearly 4 percent for circuitswitched PBX equipment and the average of almost 5 percent for intermediate technologies.

For other types of communications equipment, Gartner data were used to construct newly introduced or updated price indexes for access systems, such as modems and access multiplexers, ATM (asynchronous transfer mode) equipment, frame relay equipment, and ISDN (integrated services digital network) equipment. Also, Gartner data were used to construct price indexes for the voice-processing equipment and automatic call distributors for the 1992-2004 period.

Information was drawn from the TIA's 2005 Market Review and Forecast to generate price indexes for

10. Annual price indexes: Private branch exchange (PBX) equipment, 1999-2004

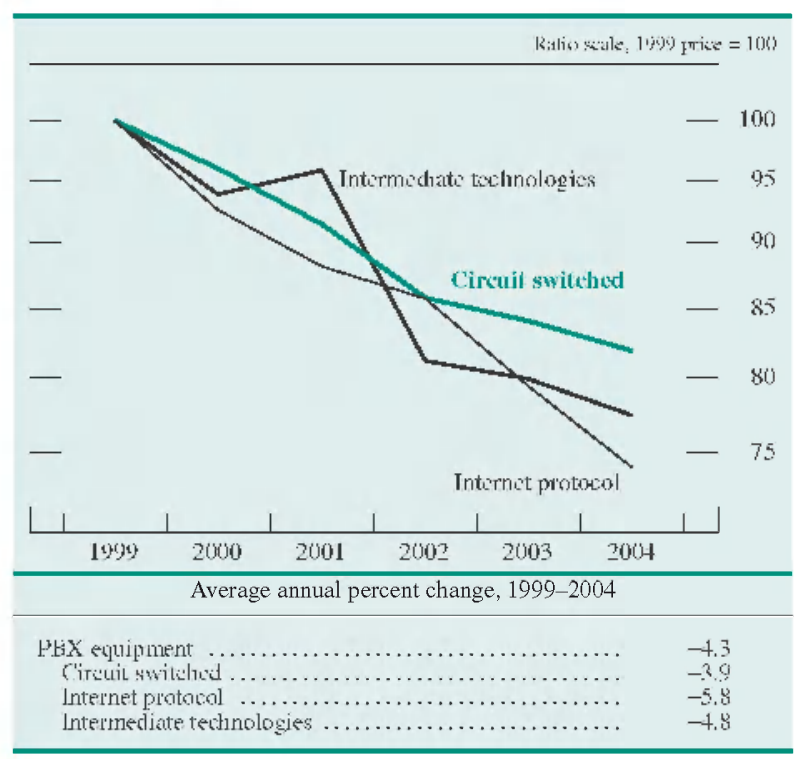


consumer telecommunications equipment, office facsimile equipment, and ATM equipment.

The remaining types of equipment without specific information on prices and quantities were assigned appropriate producer price indexes. These included broadcast studio equipment, alarm systems, vehicular and pedestrian signal equipment, and paging equipment.

\section{Discontinuance of the Survey}

of Electric Power Use

The Federal Reserve discontinued its use of survey data of industrial electric power use. The survey was initiated in the 1960s to collect data on electricity use as alternative indicators of output; electricity use tends to be highly correlated with production in capital-intensive industries. Survey data were used directly as the production indicators for industries (particularly those with highly automated assembly operations and a diverse product mix) for which product-based data were unavailable. However, by 2004 , the electric power usage covered by the survey had dropped nearly 40 percent from its peak in 1993, and several regions and industries had significant gaps. The surveys, conducted by the Federal Reserve District Banks, had especially poor response rates for District 6 (Atlanta) and District 11 (Dallas). The industries with a substantial presence in those Districts include textiles and chemicals. As noted before, the twenty industry indexes that relied on electric power use now have production-worker hours as the underlying source data for the period 1997 to the present.

In the future, the Federal Reserve hopes to incorporate information from the Census Bureau's Survey of Plant Capacity (SPC) into its estimation of production indexes for capital-intensive industries. The SPC collects data on the factory workweek; like electric power use, the workweek is an indicator of the level of operations in capital-intensive industries. Currently, the SPC data are collected only in the fourth quarter of the year, so they are insufficient for use as high-frequency indicators.

Beyond their use as a direct monthly indicator, electric power data were used in a model that extrapolates productivity in industries for which the monthly output index was based on production-worker hours. In the absence of electric power data, the model now relies on a proxy derived from survey measures of industry capacity utilization (taken from the SPC) and measures of industry capital input constructed from data in the ASM.

\section{Weights for Aggregation}

The IP index is a Fisher index. This revision uses information from the Census of Manufactures to obtain updated estimates of the industry value-added weights used in the aggregation of IP indexes and capacity utilization rates. The Federal Reserve derives estimates of value added for the electric and gas utility industries from annual revenue and expense data issued by other organizations. The weights for aggregation, expressed as unit value added, were estimated for recent years using the latest data on producer prices. Table A.8 shows the annual value-added proportions incorporated in the IP index from 1997 through 2004.

\section{Revised Monthly Data}

This revision incorporates product data that became available after the regular four-month reporting window for monthly IP closed. For example, the data on tobacco issued by the Department of the Treasury's Alcohol and Tobacco Tax and Trade Bureau are released with too great a lag to be included with monthly IP estimates; however, the data are available for inclusion in the annual revision.

\section{Revised Seasonal Factors}

Seasonal factors for all series were reestimated using data that extended into 2005. Factors for productionworker hours - which adjust for timing, holiday, and monthly seasonal patterns - were updated with data through September 2005 and were prorated to correspond with the seasonal factors for hours aggregated to the three-digit NAICS level. The updated factors for the physical product series, which include adjustments for holiday and workday patterns, used data through at least June 2005. Seasonal factors for unit motor vehicle assemblies have been updated, and projections through June 2006 are on the Board's website at www.federalreserve.gov/releases/g17/ mvsf.htm. 


\section{APPENDIX A: TABLES BASED ON THE G.17 RELEASE, FEBRUARY 15, 2006}

A.1. Revised data for industrial production for total industry

Seasonally adjusted data except as noted

\begin{tabular}{|c|c|c|c|c|c|c|c|c|c|c|c|c|c|c|c|c|c|}
\hline \multirow{2}{*}{ Year } & \multirow{2}{*}{ Jaw. } & \multirow{2}{*}{ Fel. } & \multirow{2}{*}{ Mar. } & \multirow{2}{*}{ Apr. } & \multirow{2}{*}{ May } & \multirow{2}{*}{ Juue } & & & & & & & & Quit & ITLit & & \\
\hline & & & & & & & . M11y & Allg. & sept. & Oct. & tove & Dec. & 1 & 2 & 3 & 4 & 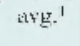 \\
\hline & & & & & & & ludust & rial prod & uction if & ercent al & augsi & & & & & & \\
\hline 1075 & -1.3 & -2.4 & -1.1 & .1 & -2 & .7 & 1.1 & 10 & 1.3 & .4 & .3 & 1.2 & -4.0 & -53 & 10.5 & 89 & -89 \\
\hline 1976 & 1.5 & (9) & .1 & .7 & 4 &.$i$ & 1. & .7 & .2 & .1 & 1.5 & 1.0 & 12.6 & 5.3 & & 7.8 & 7.8 \\
\hline $107 ?$ & -6 & 1.5 & 1.3 & 9 & 8 & 7 & 3 & i & 5 & 3 & 0 & 2 & 8.4 & 126 & 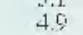 & & 7.7 \\
\hline 1978 & -1.3 & 4 & 1.8 & 3.1 & .3 & .3 & .0 & .3 & .2 & i) & .8 & .6 & -1.3 & 16.6 & 3.4 & 7.7 & 5.5 \\
\hline 1979 & -.7 & 6 & .3 & -10 & 7 & $\therefore$ & -.2 & -7 & 1 & .5 & -.1 & .1 & 1.9 & -.5 & -1.5 & 1.3 & 3.1 \\
\hline $19 \times 0$ & .4 & 0 & -3 & -20 & -2.5 & -1.3 & -.7 & 3 & 1.6 & 12 & 1.7 & 6 & 1.6 & -150 & -63 & 16.1 & -26 \\
\hline 108 & -6 & -5 & 6 & -5 & 7 & .5 & .7 & ij & -6 & -8 & -1.1 & -1.1 & 3 & 1.4 & 4.2 & -8.6 & 1.3 \\
\hline $15 x$ & -10 & 16 & -7 & -9 & -7 & -4 & -.4 & -9 & -4 & -8 & -.4 & -8 & -7.6 & -5.1 & -50 & -7.5 & -5.1 \\
\hline 1983 & 1.) & -6 & i) & 1.2 & 8 & 6 & 1.6 & 1.1. & 1.5 & i) & .3 & .5 & 4.3 & 3.4 & 14.7 & 1019 & 3.6 \\
\hline 1084 & 2.1 & 5 & 5 & 6 & 5 & 4 & 3 & $\frac{1.1}{1}$ & -2 & -1 & .4 & 1 & 12.4 & 6.7 & 2.6 & .4 & g. \\
\hline $1 \%$ & -3 & .4 & .2 & -2 & .1 & i) & -.6 & .5 & 4 & -.4 & .3 & 1.i) & 1.1 & 6 & 6 & 2.5 & 1.3 \\
\hline $15 \times$ & .5 & -8 & -6 & I & 2 & -3 & .6 & -2 & 2 & 4 & .5 & 9 & 2.3 & -2.4 & 1.7 & 4.5 & 1.0 \\
\hline 1987 & -.3 & 1.2 & .2 & 6 & .7 & .5 & .6 & .7 & .3 & 1.5 & 5 & .5 & 5.4 & $7 . j$ & 7.1 & 9.9 & 5.1 \\
\hline 1988 & 1 & 3 & 3 & 5 & 0 & .2 & .2 & 3 & -3 & 6 & 2 & 4 & 3.4 & 32 & 2.1 & 3.3 & 50 \\
\hline $198(i)$ & .3 & -.5 & 3 & -1 & -7 & $\overline{1}$ & $-\overline{9}$ & . & -3 & -.1 & .3 & .7 & 1.5 & -1.0 & -3.5 & 1.8 & .9 \\
\hline 1 i & -6 & .9 & .5 & ii & $\ddot{I}$ & .3 & -.1 & 3 & .3 & -.7 & -1.2 & -7 & 2.9 & $\begin{array}{r}-1.96 \\
3.9\end{array}$ & 1.3 & $\begin{array}{r}1.0 \\
-5 i j\end{array}$ & .) \\
\hline 1091 & -.5 & -7 & -5 & $\therefore$ & 10 & 1.0 & .0 & 2 & $\bar{c}$ & -2 & -.1 & -3 & -7.6 & 27 & 57 & 1.0 & -1.5 \\
\hline $1 \omega_{2}$ & -.5 & .7 & .3 & .7 & .4 & i) & 8 & -.5 & .3 &.$\overline{7}$ & .4 & .1 & -3 & 6.9 & 2.8 & 3.9 & 3.9 \\
\hline 1003 & .5 & 3 & 0 & $2^{2}$ & -4.7 & 3 & $\therefore$ & 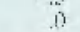 & 5 & 7 & .4 & .5 & 3.7 & 10 & 24 & 6.1 & 3 \\
\hline $1 \% \%_{4}$ & 5 & .0 & $1 . i$ & .5 & .6 & .7 & .2 & 5 & .2 & () & 6 & 1.1 & 5.3 & 7. & 5.3 & 7.9 & 5.4 \\
\hline 1005 & 3 & (1) & 2 & 0 & 2 & 3 & -.4 & 14 & $\overline{4}$ & -2 & 3 & 4 & 53 & $i$ & 37 & 3.5 & 4.8 \\
\hline 1006 & -8 & 1.5 & -.2 & i) & .7 & 8 & -.3 & .7 & .6 & $i$ & {$[i]$} & 7 & 1.8 & 8.4 & 5.1 & 6.2 & 4.3 \\
\hline 109 & .2 & 1.2 & $\overline{8}$ & -1 & 6 & .5 & .5 & 1.2 & 9 & 7 & 9 & $\ddot{4}$ & 8.5 & 5.7 & 89 & 10.6 & 7.3 \\
\hline 1998 & 4 & .1 & .1 & 5 & .6 & -.5 & -.3 & 3.2 & -.2 & .7 & -1 & 3 & 4.4 & 3.1 & 3.6 & 56 & 56 \\
\hline $160 \%$ & .5 & 5 & 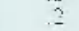 & $\therefore$ & 8 & -.1 & .7 & 5 & -4 & 1.3 & .6 & 8 & 4.1 & 42 & 4.3 & 7.7 & 4.5 \\
\hline Imoi & $\therefore$ & 4 & 4 & .7 & 3 & 1 & -3 & -3 & 4 & -3 & $\pi$ & -4 & 5.4 & 5.2 & -9 & -1.3 & 4.3 \\
\hline 20101 & -8 & -7 & -.3 & -1 & -8 & -.5 & -.4 & -3 & -.4 & -.5 & -4 &.$j$ & -6.6 & -4.9 & -5.1 & -4.5 & -3.5 \\
\hline $2 m 2$ & .6 & -1 & 9 & 4 & 4 & 9 & $-\ldots$ & 1 & 10 & -4 & $3^{3}$ & -5 & 2.9 & 61 & 17 & -1.6 & .1 \\
\hline 21013 & 5 & .15 & $\begin{array}{l}-.2 \\
-3\end{array}$ & -8 & -.1 & .3 & .5 & 1 & .7 & .1 & i) & $\frac{3}{7}$ & 8 & -3.3 & 3.6 & 5.1 & .6 \\
\hline$\frac{3 m 4}{20155}$ & .4 & $\begin{array}{l}x \\
4\end{array}$ & -3 & $\begin{array}{r}.8 \\
-.1\end{array}$ & 3 & & 6 & .3 & $-1^{-2}$ & 1.1 & 1.1 & .7 & $\begin{array}{l}5.3 \\
3.8\end{array}$ & $\begin{array}{l}5.2 \\
1.6\end{array}$ & $\begin{array}{l}2.6 \\
1.4\end{array}$ & $\begin{array}{l}4.2 \\
5.6\end{array}$ & $\begin{array}{l}4.1 \\
3.3\end{array}$ \\
\hline & & & & & & & & & & . & & & & & & $\cdots$ & \\
\hline & & & & & & & Indh & rial p & ustios & $12=$ & & & & & & & \\
\hline 197 & 46.3 & 5.2 & 44.7 & 44.7 & 446 & 149 & 45.4 & 45.8 & 46. & 46. & 46.7 & 47.3 & 45.4 & 448 & 45 & 469 & 45.7 \\
\hline & & & & & & & & & & & & & & & & & 49.3 \\
\hline 1977 & 501.8 & & & 52.6 & 5 & 53.4 & 5 & 53 & 5 & st & 5 & f. & 51 & 53 & & 54.1 & \\
\hline 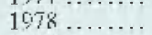 & 53.4 & & & & & & & & 56 & 57 & & & & 56 & & 57.5 & \\
\hline & 57 & 57 & & & 5 & & & & 57 & 57 & 5 & & & 57 & & 57.7 & 57.7 \\
\hline 19 & 580 & & & 567 & & 54.5 & 5 & & 5 & 55 & 5 & 572 & 57 & 55 & & 5666 & 562 \\
\hline & & & & & & & & & & & & & & 57 & & 56.3 & 56.9 \\
\hline & 5 & & & & & & & & & & & & & 34 & & & 540 \\
\hline & 5 & & & & & 54 & & 50 & 57 & 57 & 5 & 58 & 53 & 54 & & $\frac{3}{7}$ & \\
\hline 16 & 50.2 & 50 & 5 & 60.1 & & 61 & 6 & 60 & ai & 6 & 6 & & 5 & 6 & & 610 & \\
\hline & 60.8 & 61 & 61.2 & 61.1 & 61.1 & 61.2 & (1) & 61 & 61 & 61. & (1. 3 & 61 & $61 ., 1$ & 61. & & 1.4 & 6. \\
\hline & 62 & 61 & 61 & 61 & 61 & 61.3 & 61 & (i) & 61 & 61. & 6 & 62 & 61.8 & si & & 2.3 & $61 . \overline{8}$ \\
\hline 19 & 62 & 63 & & & $G$ & 6 & 6. & 65 & 6. & $6 ?$ & 6509 & 6 & 63.2 & $G$ & & 66.9 & 614.9 \\
\hline 198 & 67.2 & 67. & 67.6 & 68 & 67.9 & 68.1 & 68 & 68.5 & 68 & 68 & 68.8 & 6 & 67.4 & 68 & & 68.9 & \\
\hline 108 & 603 & $\infty 0$ & $60=$ & 60 & $6 \times 7$ & 68.7 & 68 & $6 \times 7$ & 68 & 68 & 68 & 601 & 602 & 68 & 6 & 68.7 & \\
\hline 1990 & 68.7 & (6). & $60 . \overline{6}$ & $(10) \leqslant$ & 69.6 & 60.8 & $(12) 7$ & 69.9 & 70 & (6). & 68.7 & 68,3 & 6192 & 6). & & 68.8 & $6 \% .4$ \\
\hline 109 & 67.9 & 67 & 67. & 67.2 & 67.9 & 68.6 & 68 & 887 & 69 & 60 & 60.1 & 689 & 67.5 & 77 & $6 x$ & 600 & 683 \\
\hline $1^{9}$ & 68 & 6) & (6) & 70,01 & 71). & 701. & 71 & 70 & 70 & 71 & 31 & 71 & 69.1 & 70 & 7 & 71.3 & 70.3 \\
\hline & 71 & 7. & & & 72 & 7 & 7. & 7 & & 7 & & & 72 & 72 & & & 7. \\
\hline & 78 & & & & & & & 77 & 7 & 7 & 7 & & 74 & & & 78.5 & \\
\hline & $70 \mathrm{~s}$ & & & & 70 & $\dot{7}$ & & xil & & 8 & & 8 & & 70 & & & \\
\hline 1966 & 80.7 & 82 & \&1. & 80.5 & 83.1 & 83.8 & 83 & 84.2 & \& & 84 & 8 & $x 6$ & 81.5 & 83 & 8 & 85.5 & 8 \\
\hline 100 & 862 & 87 & $8 \mathrm{~B}$ & 84 & $8 x$ & 88 & B & ai? & 5 & c) & 9 & 9 & 87.2 & 88 & 5 & $\begin{array}{l}6.7 \\
92.7\end{array}$ & \\
\hline & 93.6 & c) & 03 & & 94 & 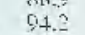 & 0 & 98 & 0 & 9.5 & 96.4 & 967 & 93.7 & $\mathrm{c} 4$ & of 2 & 96.5 & 94.9 \\
\hline & 97.1 & 97 & i) & & is & (3) & & is & & & & & & 98.5 & & & \\
\hline & 102.4 & 1028 & & & 10 & 10 & & 1036 & 10 & 7 & in & $\frac{5}{2}$ & 1028 & 114.1 & 10 & 103.5 & 105.5 \\
\hline & $102+4$ & 101.6 & 101. & & 100.4 & 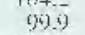 & & & & 198.3 & (9) 79 & 979 & 101.8 & 100) & & 98.1 & 90,9 \\
\hline 20012 & 98.6 & 58.4 & 003 & 00.7 & 100.1 & 1010 & 1606 & 1007 & 100 & 1013 & 10115 & 1001 & $9 \times 8$ & 1003 & 10 & 100.3 & 1000 \\
\hline & 10ij. 5 & . & 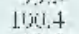 & & gt & (36) & & . & 11. & . & & & & 90.7 & & & \\
\hline & 102.7 & & & & 10 & & & & 10 & & & & & 1124.4 & 10 & & 1014.7 \\
\hline 20 & 1069 & 107.4 & 107.3 & 107.2 & 107.4 & 108.3 & 1083 & 108.6 & 107.2 & 108.4 & 1092.5 & 110.5 & 107.2 & $\begin{array}{l}11.4 .4 \\
117.6\end{array}$ & 1080 & liiv. .5 & 104.2 \\
\hline 2016 & 110.3 & & & & & & & & & & & & & & & 1.. & \\
\hline
\end{tabular}

NotE: Monthly percent change figures show the change from the previous month; quarterly figures show the change from the previous quarter at a compound annual rate of change. Production and capacity indexes are expressed as percentages of output in 2002.
Estimates from November 2005 to January 2006 are subject to furthe revision in the upcoming monthly releases.

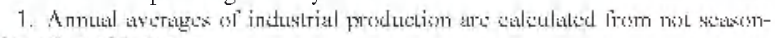
ally adjusted inderes.

.. Xot available as of Fehruary 15, 20066. 
A.2. Revised data for capacity and utilization for total industry

Seasonally adjusted data except as noted

\begin{tabular}{|c|c|c|c|c|c|c|c|c|c|c|c|c|c|c|c|c|c|}
\hline \multirow{2}{*}{ Year } & \multirow{2}{*}{ Jaul. } & \multirow{2}{*}{ teb. } & \multirow{2}{*}{ Mar: } & \multirow{2}{*}{ Apr. } & \multirow{2}{*}{ May } & & & & & & & & & Qui: & artet & & \\
\hline & & & & & & Julle & luly & Allg. & sept. & Oct. & - & Dec. & 1 & 2 & 3 & 4 & 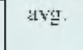 \\
\hline & & & & & & & Cap & acity & Ent & 120 & muti & & & & & & \\
\hline 1975 & 50.8 & 59.9 & 6010 & 60.2 & $60 ;$ & 601.4 & 60.5 & 606 & 007 & 80.8 & 61.0 & S1. 1 & 500 & 611.3 & 606 & 61.9 & 60.4 \\
\hline 1976 & 61.2 & 61.3 & 61.5 & 61.6 & 61.7 & 61.i) & (3. 11 & 6..1. & 62.3 & 62.4 & 63.61 & 63.7 & 61.3 & 61.3 & 62.1 & 62.6 & (11.9) \\
\hline $107 ?$ & 620 & (3)in & 632 & 63.4 & 63.7 & 63.7 & 630 & 84.1 & 643 & 645 & 64.6 & $64 x$ & 830 & 63.5 & 641 & 64.6 & 638 \\
\hline 1978 & 650 & 67.2 & 654 & 696 & 69.7 & 0.59 & 60.1 & 66.2 & 664 & 66.6 & 66.7 & 669 & 652 & 6.5 .7 & 6622 & 66.7 & 660 \\
\hline 1979 & 6721 & 67.2 & 63.3 & 67.5 & 67.7 & 67.8 & $6 \times .15$ & 68.1 & 68.3 & 68.4 & $6 \times .5$ & 68.7 & 67.2 & 617.7 & 68.1 & 68.5 & 67.9 \\
\hline $1980 !$ & $6 \times 8$ & $6 \times 0$ & 691 & 60.2 & 603 & 695 & 60.6 & 608 & 699 & 7000 & 70,2 & 703 & 689 & 603 & 608 & 701.2 & 69.6 \\
\hline 1981 & 70.5 & 70.6 & 70.8 & 70.9 & 71.1 & 71.3 & 71.4 & 71.6 & 71.8 & 71.9 & 73.1 & 713 & 70.6 & 71.1 & 71.6 & 72.1 & 71.4 \\
\hline 1982 & 72.5 & $\pi 26$ & 728 & 729 & 73.1 & 73.3 & 73.4 & 7.5 & 736 & 73.7 & 73.8 & 79 & $T 26$ & 73.1 & 73.5 & 73.8 & 73 \\
\hline 1983 & 74,01 & 74.0 & 74.0 & 74.1 & 74.1 & $7+.1$ & 74.1 & 74.2 & 74.2 & 74.3 & 74.3 & 74.4 & 74.01 & 74.1 & 74.1 & 74.3 & 74.3 \\
\hline $10 \times 4$ & 74.5 & 745 & 746 & 74.7 & 740 & 750 & 75.1 & 75.3 & 774 & 756 & 75.7 & 760 & 746 & 749 & 753 & 75.7 & 75.1 \\
\hline 1085 & 76.1 & 76.3 & $766_{1} 5$ & 760. & 76.8 & 7701 & 77.1 & 77.4 & 77.5 & 77.7 & 778 & 77.9 & 76.3 & 76.8 & 77.4 & 778 & 77.1 \\
\hline 1586 & $7 \times .1$ & 78.2 & 78,3 & $7 \times, 4$ & 78.5 & 78.6 & $7 \times 6$ & 787 & $7 \times 8$ & $T 80$ & 790 & 79.1 & $T R ?$ & 78.5 & $7 \times 7$ & 790 & 78.6 \\
\hline 1987 & 70,3 & 794 & 795 & 75,7 & 79.8 & 799 & 81). & 80.2 & (1) 3 & Xil 4 & 80.5 & $\sin 6$ & 794 & 79.8 & (1) 2 & 80.5 & 80,0 \\
\hline 1088 & sof & 80.7 & sii.8 & so.s & 80.9 & siii) & sib? & 81.15 & \&1.1 & 81.1 & 81.2 & 81.3 & 801.7 & $80.5)$ & 81.0 & 81.2 & 80.9 \\
\hline 1980 & 81.4 & $\times 1.5$ & 81.7 & 81.8 & $\times 20$ & $x \geq 1$ & 82.1 & $\times 2.5$ & 826 & 82.8 & $8 ., 0$ & 83,2 & $\times 1.5$ & 82,0 & 82.5 & 830 & 82.2 \\
\hline 1930 & 83.3 & 83.5 & 83.7 & 83.9 & 84.15 & $8 \overrightarrow{4} .2$ & 84.3 & 84.5 & $\$ 4.6$ & 84.8 & (84.) & 85.13 & 83.5 & $84 . i 1$ & 84.5 & 84.9 & 84.2 \\
\hline 1001 & 85.2 & 853 & 854 & 85.5 & 856 & 85.8 & 859 & 860 & 861 & x6. 2 & 863 & 865 & 853 & 85,6 & 860 & 86.3 & 8.8 \\
\hline 1992 & 860 & 86.7 & $8(0, i)$ & 870 & 87.1 & 873 & 87.5 & 87.6 & 87.8 & 88.7 & 88.1 & 883 & 86.7 & 87.2 & 87.6 & 88.1 & 87.4 \\
\hline 1003 & $8 \times .4$ & $x \times 5$ & 88.7 & $8 \times 8$ & 88.9 & 80.1 & 89.2 & $80 ?$ & 89.5 & 80.6 & 80.8 & 0017 & 86.5 & 880 & 89.3 & 89.8 & 89.2 \\
\hline 1904 & 90.1 & 90.3 & ivi.5 & 910.8 & 91.0 & 11.2 & 91.5 & 91.8 & ig. 1 & 92.4 & i) 2.8 & 133.1 & 90.3 & i) $1 . i 1$ & 131.8 & 92.8 & 9) 1.5 \\
\hline 19095 & 93.5 & 938 & 942 & 94.6 & 0,510 & 05.4 & 05.8 & 962 & 966 & $0,70)$ & $97 \overline{3}$ & 978 & 98 & 950 & 962 & 0.7 .5 & 0.6 \\
\hline 1906 & 983 & 18.7 & (3i) $\overline{2}$ & 9961 & (190.1) & Lijit & libis? & 161.3 & 101.7 & 102.2 & 1013.7 & 10.1 & 98.7 & liingi, & 101.3 & 102.7 & liiij.? \\
\hline 1947 & 1013.6 & 164.2 & $10+7$ & 1015.2 & 1058 & 106.4 & 1017.0 & 107.7 & 1084 & (10i) $\pi$ & Lij 5.7 & 110.5 & $10+2$ & 105.8 & 1077 & (jij).7 & 1016.9 \\
\hline 1008 & 111.2 & 1115 & 1126 & 1133 & 1140 & 114.6 & 115.2 & 1158 & 1164 & 1169 & 1175 & 1180 & 1119 & 1140 & 1158 & 117.5 & 114.8 \\
\hline $19(9)$ & 118.5 & 119.13 & 110.5 & 12101 & 130.5 & 1.30 .3 & 121.4 & 111.8 & 133.3 & 132.8 & 123.2 & 139.7 & 1.9. & $121) .4$ & 121.8 & 133.2 & 121.1 \\
\hline 2000 & 124.2 & 124.6 & 125.1 & 125.5 & $126 n$ & 126.4 & 126.8 & 1272 & 127.7 & 128.1 & 128.5 & $12 \times 9$ & $12+6$ & 1260 & 1272 & 128.5 & 1266 \\
\hline $2 \mid j i j]$ & 125.2 & 132.6 & 1,3010 & 131.3 & 1315.6 & $13(1, i)$ & 131.2 & 1315 & 131.8 & 132.1 & 133.2 & 1325 & (13i). 6 & 13116 & 1315 & 132.2 & $131.1 \mathrm{j}$ \\
\hline 2002 & 132.6 & 1328 & 1329 & 1330 & 133.1 & 133.2 & 13.3 & 133.2 & 1332 & 1332 & 133.2 & 1332 & 132.8 & 13.3 .1 & 13.12 & 133.2 & 133.1 \\
\hline 20003 & 133.1 & 133.1 & 133.0 & 1330 & $133.1)$ & $132 i)$ & 1319 & 132.9 & 130.9 & $(32.9$ & $133 i 3$ & 131.9 & 133.1 & 1330 & 132.9 & 132.9 & 133.0 \\
\hline 2014 & 1330 & 1330 & 1330 & 133.1 & 133.1 & 133.2 & 133.3 & 1334 & 133.5 & 1336 & 133.7 & 1330 & 1330 & 133.1 & 1334 & 133.7 & 1333 \\
\hline 20105 & $134, i \mathrm{i}$ & 134.2 & 134.3 & 134.5 & 134.7 & 134.9 & 135.1 & 135.3 & 135.5 & 135.7 & $1355^{\circ}$ & 136.1 & 134.2 & 134.7 & 135.3 & 1359 & 135.0 \\
\hline 2006 & 1383 & 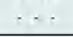 & 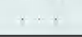 & $\cdots$ & & $\ldots$ & & - & 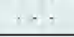 & & $\ldots$ & $\ldots$ & - & $\ldots$ & & $\cdots$ & $\cdots$ \\
\hline & & & & & & & & Tril & $m$ & int) & & & & & & & \\
\hline 1975 & 77.4 & 753 & $74+$ & 74.3 & 74.1 & 74.4 & 75.1 & 756 & 76.5 & 76.6 & 766 & 774 & 75.7 & 7.43 & $7 \pi 7$ & 760 & 75.6 \\
\hline 1976 & $7 \times .4$ & $7 \times 9$ & 78.8 & 79.2 & 70.3 & 70.2 & 79.4 & $70 x$ & 798 & 79.8 & 80.8 & 8. 4 & 78.7 & 70.2 & 70.7 & 80.6 & 70.6 \\
\hline 1977 & 81.7 & 81.7 & $\$ 2.5$ & 83.1 & 83.5 & 83.8 & 43.8 & 89.7 & 83.8 & 83.8 & 836 & 83.5 & 81.7 & 83.5 & 83.8 & 83.6 & 83.1 \\
\hline 1978 & 82.1 & 823 & 83.5 & 850 & 85.1 & $x 5_{-} 5$ & 8.52 & 853 & 853 & 858 & 863 & 866 & 82.6 & 85.2 & 8.3 & 86.2 & 84.8 \\
\hline 1979 & 85.8 & 86.1 & $8 r_{1,2}$ & 85.1 & 85.5 & 853 & 45,0 & 84.2 & 84.1 & 84.4 & 84.1 & 84.1 & 86,0 & 85.3 & 84.4 & 84.2 & 85.6 \\
\hline 10801 & 84.2 & $x 4.1$ & 83.7 & 819 & $\pi 06$ & 78.5 & 778 & 779 & 7911 & 798 & 81.0 & 81.3 & $8+01$ & 8100 & $7 \times 2$ & 80.7 & 80.7 \\
\hline 1981 & 815.7 & $81 j .1$ & \&ii.4 & 79.8 & 810.1 & $8 \mathrm{ii} .4$ & 80.7 & 810.6 & 79,9 & 79).1 & 78.1 & 77.0 & 80.4 & 80.1 & $81 j .4$ & 78.1 & 79.7 \\
\hline 1682 & 75.4 & 766 & 759 & 75.1 & 744 & 74.1 & 736 & 726 & 72.5 & 71.8 & 71.4 & 707 & 760 & 745 & 73.0 & 71.2 & 73.7 \\
\hline $10 \times 3$ & 730 & $71 \ldots 5$ & 72.1 & 730 & 73.4 & 73.8 & 74.9 & 75.7 & 76.8 & 77.5 & 776 & 77.9 & 71.8 & 73.4 & 75.8 & 77.7 & 74.7 \\
\hline 1584 & 79. & $\pi 0.7$ & xhio & 80.4 & 807 & 801.8 & 800 & सiा 0 & 816 & $x 01.3$ & 81,5 & $\sin 3 \hat{x}$ & 79.7 & 811.7 & का $x$ & 801.4 & 80.4 \\
\hline 108 & 700 & 80.1 & 8001 & 707 & 796 & 794 & $7 \times 7$ & 789 & 70.1 & 78.6 & 78.8 & 70,4 & xio & 796 & 789 & 789 & 79.4 \\
\hline 1980 & 7073 & $79.1)$ & 78.4 & 783 & 78.4 & 78.9 & 784 & 78.1 & 78.3 & 78.5 & 78.7 & 793 & 79.0 & 782 & 78,3 & 78.9 & 78.6 \\
\hline 1587. & 70.0 & 708 & 79.8 & 80.1 & $\sin 6$ & 80.8 & 81.2 & 816 & 817 & 82.8 & 8.3 .1 & 834 & 796 & 80.5 & 815 & 83.1 & 81.2 \\
\hline 198 & 83.4 & 83.6 & 83.7 & 84.1 & 84.0 & 84.2 & 84.3 & 84.6 & 84.3 & 84.7 & 84.8 & 85.15 & 83.6 & 84.1 & 84.4 & 84.8 & 84.2 \\
\hline 1080 & 85.1 & 846 & 84.7 & 84.5 & 838 & 83.6 & 82.7 & 83.3 & 828 & 826 & 82.7 & 831 & $8+8$ & 84.1 & 82.9 & 82.8 & 836 \\
\hline 1900 & 83.4 & 82.9 & 83.2 & 830 & 83.6 & 829 & 83.7 & 87.8 & 82.8 & $82, i$ & Biji) & (ख) $?$ & 82.8 & 829 & 83.7 & 81.1 & 82.4 \\
\hline 1001 & 70.7 & 70.1 & 786 & $7 \times 6$ & 703 & $80 ! 0$ & 706 & 709 & 80.5 & 80.2 & 810 & $70 . \overline{7}$ & 79.1 & 70,3 & 801 & 8010 & 79.6 \\
\hline $19 y 2$ & 79.1 & 73.5 & $8(i, i)$ & 80.4 & 810.6 & 8 ii 5 & 81.10 & $81 j .4$ & 80.5 & $8(1, \overline{4})$ & 81.0 & 81.0 & 76.6 & 80.5 & $81 j .6$ & $81 . i$ & 80.4 \\
\hline 1093 & 81.2 & 814 & 81.3 & 81.4 & 810 & 81.1 & 81.2 & 81.1 & 814 & 81.8 & 8201 & 823 & 813 & 81.1 & 81.2 & $82 ! !$ & 81.4 \\
\hline 1004 & 83.5 & 82.3 & $83, i$ & 43.2 & 83.5 & 83.8 & 43.8 & 83.5 & 83,8 & 84.2 & 84.5 & 85.10 & 8261 & 83.5 & 83.8 & 846 & 83.6 \\
\hline 1505 & 85.01 & 84.7 & 84.5 & 84.1 & 83.9 & 83.8 & 83.1 & 83.5 & 83.8 & 83.3 & 83.2 & 83.1 & 84.7 & 83.9 & 83.6 & 83.2 & 83.9 \\
\hline 1006 & 821 & 83.17 & 82.5 & 829 & 83.1 & 83.5 & 830 & 832 & 833 & 820 & 83.3 & 8.5 & 82.5 & 83.2 & 831 & 83.3 & 830 \\
\hline 1997 & 83.3 & 83.9 & 84.1 & 83.6 & 83.6 & 83.5 & 83.5 & $84.1)$ & 84.3 & 84.3 & 846 & 84.4 & 83.7 & 836 & 83.9 & 84.4 & 83.9 \\
\hline 109 & 84.2 & 83.7 & 83,3 & 8.1 & 8.1 & 82.2 & 81.5 & 828 & $\times 2.3$ & $x_{2} .5$ & 82.1 & 819 & 83.7 & 82.8 & 82.2 & 82.2 & 82.7 \\
\hline 1960$)$ & 83.11 & 87.0 & 81.8 & 81.7 & 83.15 & 81.7 & 81.9 & 80.0 & $\$ 1.3$ & 82.1 & 83.2 & 83.6 & 81.9 & 81.8 & 81.7 & $82 . \overline{3}$ & 81.9 \\
\hline $2 m 0$ & 82.5 & 82.5 & 82.5 & 82.7 & 82.7 & 82.5 & 82.0 & 814 & 815 & 8rig & 80.7 & 801 & 82.5 & 82.6 & 816 & 80.6 & 81.8 \\
\hline 2001 & 70.2 & 78.4 & 77.9 & 77.61 & 76.9 & 76.3 & 75.9 & 75.4 & 75,0 & 74.5 & $74 i$ & 73,9 & 78.5 & 76.9 & 75,4 & 74.2 & 76.3 \\
\hline 20192 & $74 . .3$ & 74.1 & 74.7 & 749 & 75.2 & 75.8 & 756 & 756 & 756 & 75.2 & 75.5 & 75.2 & 74.4 & $7,7.3$ & 756 & 753 & 75.1 \\
\hline 20053 & 75.5 & 75.6 & 75.4 & 749 & 74.9 & 75.1 & 75.4 & 75.5 & 76.15 & 76.1 & 36.8 & 76.9 & 75.5 & $74 i)$ & 75.6 & 76.6 & 75.7 \\
\hline 2974 & 77.2 & 778 & 776 & $7 \times 1$ & 788 & 78.4 & 788 & 7901 & 78.7 & 702 & 79.3 & $7 \mathrm{ci} 7$ & 775 & 78.4 & 788 & 79.4 & 786 \\
\hline 20105 & 798 & 8100 & 79.9 & 70.7 & 798 & 801.2 & 80.2 & $813 ;$ & 79.1 & 790 & 81.6 & 81.2 & 799 & 790 & 798 & 8016 & 80.1 \\
\hline 20000 & 80.9 & $\ldots$ & $\ldots$ & $\ldots$ & $\ldots$ & $\ldots$ & $\ldots$ & $\ldots$ & $\ldots$ & $\ldots$ & $\ldots$ & $\ldots$ & $\ldots$ & $\ldots$ & $\ldots$ & $\ldots$ & $\ldots$ \\
\hline
\end{tabular}

Note: Refer also to the general note in table A.1. 
A.3. Rates of change in industrial production, by market and industry groups, 2001-05 ${ }^{1}$

\begin{tabular}{|c|c|c|c|c|c|c|c|c|c|c|c|}
\hline \multirow[t]{2}{*}{ Tu:m } & \multirow{2}{*}{$\begin{array}{l}\text { NATES } \\
\text { tode } 2\end{array}$} & \multicolumn{5}{|c|}{$\begin{array}{l}\text { Revised rate of thauge } \\
\text { (percent) }\end{array}$} & \multicolumn{5}{|c|}{ 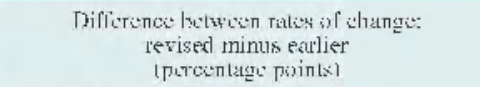 } \\
\hline & & 20011 & $20 ! 2$ & 20113 & 20104 & 2095 & 20011 & 2012 & 20103 & 2014 & 20115 \\
\hline Tutal industry .. & $\cdots$ & -5.3 & 2.3 & 1.5 & 4.3 & 3.1 & -.2 & .8 & 3 & .0 & .2 \\
\hline \multicolumn{12}{|l|}{ MAkKLI Cinoly } \\
\hline Fiual products aud nouiudustrial supplies .. & $\ldots$ & -4.6 & 1.5 & 1.7 & 4.3 & 4.7 & i) & 8 & .j) & -.4 & .2 \\
\hline Cousumer yoods. & $\ldots$ & -1.3 & 3.7 & 1.3 & $2 . i$ & 3.3 & .2 & 1.1 & .1 & -1.6 & .5 \\
\hline 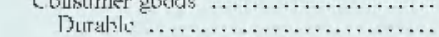 & $\cdots$ & -1.3 & 70 & 4.3 & 1.3 & 3.1 & 0 & 1.1 .5 & 10 & $\begin{array}{r}-1.0 \\
-.2\end{array}$ & .5 \\
\hline Automotive products ................. & $\ldots$ & 2.7 & 13.4 & 6.5 & .4 & 2.5 & .4 & 2.3 & 1.3 & -.2 & $-\ddot{i}$ \\
\hline Home dixtremics & $\cdots$ & 63 & -7.7 & 18.5 & -3.7 & 164 & .5 & -3.7 & -16.4 & 4.4 & 15.2 \\
\hline Appliances, lumiture, campeting .... & $\ldots$ & -2.9 & 40 & 2.2 & 2.4 & 2.4 & .5 & 2.2 & 8 & -6 & .5 \\
\hline Miscellaneous goods ............... & $\ldots$ & -7.5 & 4.9 & -.7 & 3.0 & 3.7 & $-i$ & .6 & 2.8 & 4 & $\ddot{1.1}$ \\
\hline Simdurable & $\ldots$ & -1.3 & .8 & .1 & 2.3 & 2.0 & .2 & 10 & -3 & -1.4 & .4 \\
\hline 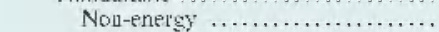 & $\ldots$ & -.5 & $-1 . i$ & 6 & 2.5 & 1.) &.$\overline{3}$ & 1.3 &.- .3 & -1.8 & i) \\
\hline 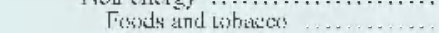 & $\cdots$ & -4 & -3.1 & 2.1 & 1.8 & 2.4 & .8 & 6 & -3 & -2.6 & .4 \\
\hline Clothing ........... & $\ldots$ & -21.5 & -7.1 & $-i) .3$ & -2.8 & -1.0 & -.7 & 2.6 & 5.6 & 2.3 & 5.1 \\
\hline C'hemical products & $\cdots$ & 6.5 & 40 & $11)$ & 30 & 4 & -6 & 3.1 & 4 & -1.1 & -1.4 \\
\hline Paper products $\ldots \ldots \ldots \ldots \ldots \ldots$ & $\ldots$ & -2.3 & -.5 & -3.5 & 5.9 & 3.5 & 4 & .3 & -4.1 & -1.1 & .3 \\
\hline 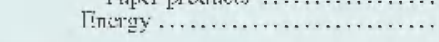 & $\cdots$ & -53 & 9.5 & -1.5 & 1.7 & 24 & -.1 & -6 & -.5 & $\frac{1.2}{7}$ & 2.1 \\
\hline business equipment & $\ldots$ & -13.6 & -3.3 & 2.8 & 10.8 & 10.4 & -.3 & .3 & -1.5 & $1.0 j$ & -1.1 \\
\hline 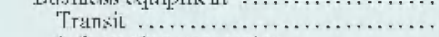 & $\cdots$ & -4.6 & -10.8 & 3.6 & 9.7 & 14.1 & -1.2 & 19 & 3.5 & -1.2 & 1.7 \\
\hline 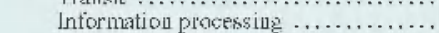 & $\ldots$ & -1.5 .5 & $-8 i)$ & 6.5 & 146 & 19,4 & $1 . \overline{9}$ & -5.3 & $-i) .8$ & 4.6 & .3 \\
\hline Tndustrial and wher & $\cdots$ & -153 & 5.4 & 4 & 9.2 & 4.4 & -1.6 & 3.4 & 9 & -2 & -2.4 \\
\hline Defense and space equipment...$\ldots \ldots$ & $\cdots$ & 8.4 & 8 & 5.4 & 9.7 & 9.2 & 4 & $-3.1 j$ & .1 & 3.6 & -1.2 \\
\hline Coustruction supplies ................. & $\ldots$ & -5.0 & 1.2 & 1.7 & 4.6 & 6.8 & i) & 1.1 & 1.1 & .7 & -.1 \\
\hline Business stppplies & $\cdots$ & -5.5 & 2.5 & 9 & 3.9 & 3.8 & 9 & 1.1 & 8 & -10 & .8 \\
\hline Makrials .... & ... & -6.1 & 3.4 & 1.2 & 4.3 & 9 & -.5 & .7 & .7 & .7 & .1 \\
\hline 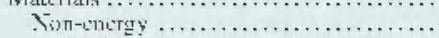 & $\cdots$ & -7.2 & 4.4 & 1.7 & 6.0 & 34 & -.7 & 9 & 9 & .5 & .7 \\
\hline 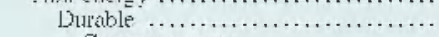 & $\ldots$ & -8.3 & 5.4 & 3.3 & 76 & 7.2 & $-1 i$ & . & 1.7 & .6 & 1.5 \\
\hline Cemsumet parts & $\ldots$ & -7.7 & 60 & -1.2 & 20 & 2.1 & .2 & -10 & -39 & -2 & .2 \\
\hline Equipment parts .................. & $\ldots$ & $-i) .4$ & 7.4 & 11.8 & 14.1 & 16.5 & $-1 . \overline{5}$ & 1.3 & $6.1)$ & -3.0 & (i) \\
\hline Ohner & $\cdots$ & -7.3 & 3.4 & i) & 4.9 & 2.2 & -1.1 & 1.4 & 9 & 2.3 & 2.1 \\
\hline 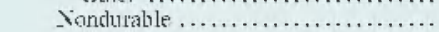 & $\ldots$ & -5.1 & 2.7 & -1.7 & 3.2 & -3.6 & (i) & 1.6 & -.4 & .3 & -.7 \\
\hline 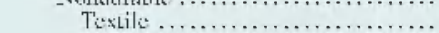 & $\cdots$ & -10.3 & 4.9 & -6.5 & -6.4 & -4.7 & -8 & 2.9 & 6.5 & -1.0 & .8 \\
\hline 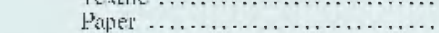 & $\ldots$ & -0.3 & 8 & -6.5 & 46 & -.9 & .1 & -1.3 & -2.1 & 1.4 & -.8 \\
\hline 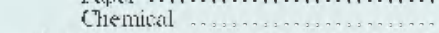 & $\ldots$ & -4.5 & $4 i i$ & 1.6 & 5.3 & -8.3 & i) & 1.8 & -5 & 4 & -2.1 \\
\hline 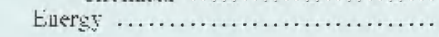 & $\ldots$ & -2.8 & 4 & -1 & -.2 & -5.1 & i) & . & .2 & 1.0 & -1.2 \\
\hline
\end{tabular}

Table A.3. continues on page A54. 
A.3. Rates of change in industrial production, by market and industry groups, 2001-05 1 — Continued

\begin{tabular}{|c|c|c|c|c|c|c|c|c|c|c|c|}
\hline \multirow[t]{2}{*}{ Them } & \multirow{2}{*}{$\begin{array}{l}\text { NATC'S } \\
\text { tode }\end{array}$} & \multicolumn{5}{|c|}{$\begin{array}{l}\text { Rerised rate of thauge } \\
\text { (percent) }\end{array}$} & \multicolumn{5}{|c|}{ 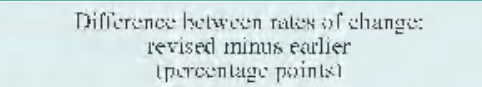 } \\
\hline & & 201011 & $2 m ?$ & 20103 & 20114 & 2005 & 2001 & 2002 & 20113 & 20104 & 20115 \\
\hline \multicolumn{12}{|l|}{ INTMSTRY GROT.P } \\
\hline Manulacturing: & & -56 & 2.2 & 1.7 & 5.1 & 4.2 & $-\hat{2}$ & c & 2 & 1 & 2 \\
\hline Manufacturiug (NAICsi... & $31-33$ & -5.6 & 3.5 & 20 & 5.2 & 4.3 &.$- \overline{3}$ & 6 & $\overline{4}$ & 1 & .2 \\
\hline Duralsle mamufucturines & & -7.7 & 38 & 4)$. & 7.1 & 78 & -.5 & .7 & .7 & 5 & 6 \\
\hline Wood produets.... & 321 & -1.3 & 9) & $4 . j$ & $3 . i$ & 7.8 & .4 & l) & .8 & 2.2 & 4.5 \\
\hline Nenmetiallic minesal products & 327 & -34 & 10 & 2.2 & 5.1 & 3.2 & -9 & 7 & .5 & $-\overline{7}$ & -1.8 \\
\hline Primary metal .................... & 331 & $-1,3$ & 6.6 & 10 & 3.9 & -1.6 & -6 & -.4 & 3 & .6 & 26 \\
\hline Thabricialed metal products & 332 & -10.5 & 1.2 & -.7 & 5.2 & 4.1 & -1.0 & 1.5 & 2.2 & 2.0 & 1.2 \\
\hline Mastrinery & 333 & -18.6 & 4.2 & $1 i$ & 11.5 & 6.4 & -1.8 & 20 & .3 & -4 & -3.6 \\
\hline Computer and electrouic praclucts .. & 334 & -8.9 & 3.9 & 15.7 & 16.1 & 73.3 & -1 & -7.8 & 1.2 & .9 & i) \\
\hline 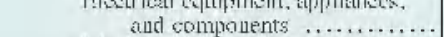 & 335 & -14.8 & -3.3 & -.7 & 5.2 & 6.8 & -.2 & 3.1 & -1.9 & -.8 & 4.5 \\
\hline Miskor richicles and parts. & $3361 ;$ & -18 & 12.2 & 4.7 & 26 & 23 & $\hat{2}$ & 10 & -1 & -3 & .8 \\
\hline 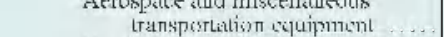 & 33640 & 5.1 & -7.3 & -.4 & 5.3 & 11.5 & .5 & .2 & -1.2 & 8 & -1.0 \\
\hline Furniture and related products .... & 337 & -6.9 & 7.3 & .3 & 2.2 & -2.15 & -.1 & 3.1 & 2.1 & -.1 & -8 \\
\hline Miscellameestax .... & 339 & -1.5 & 96 & 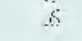 & 39 & 4.8 & .1 & 2.2 & 2.8 & -4 & 9 \\
\hline Cinndurable mauracturing.... & $\ldots$ & -2.9 & $\&$ & -.4 & 2.8 & -.1 & .1 & 1.2 & i) & -.3 & -.4 \\
\hline 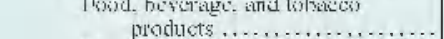 & 31.2 & -.7 & -1.2 & 1.7 & 1.7 & 3,6 & .7 & .7 & -4 & -3.2 & .5 \\
\hline Texsile and pridust mills.... & 313,4 & -0.9 & $\frac{-12}{2}$ & -4.2 & -39 & $\frac{1}{5}$ & -.4 & $\ddot{1} \ddot{x}$ & 4.3 & -1.4 & 1.6 \\
\hline Apparel and leather ........ & 315.6 & -11.9 & -6.9 & $-i) .4$ & -2.2 & -1 & -8 & 3.4 & $4 i)$ & 2.4 & 5.7 \\
\hline Pepт ...................... & 322 & -50 & 34 & $-6 i 0$ & 4.5 & $-\overline{7}$ & 8 & -7 & -2.7 & 1.2 & -9 \\
\hline Printing and support ................ & 323 & $-i), 0$ & -3.2 & -30 & 1.5 & 1.6 & $-i)$ & .) & -5 & .6 & .1 \\
\hline Petroleum and oval productx. & 324 & $1.1)$ & 2.9 & i & 6.2 & -6.3 & .2 & -1.2 & -9 & 2.2 & -.8 \\
\hline Chemical ................... & 375 & 1 & 3.6 & .7 & 4.2 & -3.3 & $-\overline{1}$ & 3.6 & -.5 & .6 & -2.1 \\
\hline Plastics and rublexer products. & 326 & -5.1 & 4.4 & $-\because$ & 3.2 & 36 & -6 & 1.9 & 1.9 & 1.6 & 1.2 \\
\hline Other mauraturing i uon-NAlCsi . & $1.133,5111$ & -5.5 & -1.6 & $-3 . i j$ & 3.7 & 1.7 & .8 & 1.4 & -3.2 & -1.4 & .3 \\
\hline Miniug.... & 21 & -.7 & -3.8 & 5 & -4 & -6.3 & a & -.1 & .3 & 1.6 & -1.6 \\
\hline Titilitios .......................................... & 2211.2 & -52 & $\pi$ &. $\bar{T}$ & 1.2 & 3.3 & -.1 & -1 & 1.3 & -1.5 & 2.2 \\
\hline 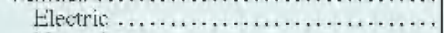 & 2211 & -3.8 & 5.6 & 1.9 & $2 . \overline{1}$ & 4.8 & -.1 & -.1 & 1.4 & -1.7 & 1.7 \\
\hline Niutural gias . . . . . . . . . . . . . . . . & 2212 & -120 & 1.55 & -5.9 & -29 & -36 & -1 & 1 & .7 & -4 & 4.6 \\
\hline
\end{tabular}

NoTE: Estimates for the fourth quarter of 2005 are subject to further revision in the upcoming monthly releases.

1. Rates of change are calculated as the percent change in the seasonally

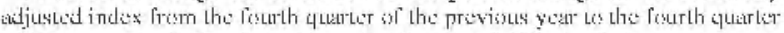
of the year specitied in the columu heading. For 20115 , the ditterence between the rates of change are calculated from anulalized rates of change between the fourth guarker of 2004 and the Lhird guarker of 2005

2. Vorth American Lndustry Classitication System.

3. Manufacturing comprises North American Industry Classitication System

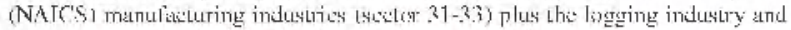
the newspaper. periodical. book. and directory publishing industries. Loggille

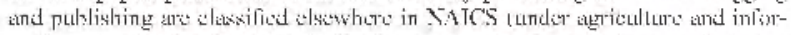
mation repectively!. but historically they were considered to be manufacturing industries and were included in the industrial sector under the Standard Indusurial Claxsificution (STC) system. In December 20102 the Federal Reserve reclassitied all its industrial output data from the SIC swstem to XAICS.

.. Nis upplicathe. 
A.4. Rates of change in industrial production, special aggregates and selected detail, 2001-051

\begin{tabular}{|c|c|c|c|c|c|c|c|c|c|c|c|}
\hline \multirow[t]{2}{*}{ TLem } & \multirow{2}{*}{$\begin{array}{l}\text { NATK'S } \\
\text { bade } 2\end{array}$} & \multicolumn{5}{|c|}{$\begin{array}{l}\text { Revised rate of change } \\
\text { (percint) }\end{array}$} & \multicolumn{5}{|c|}{ 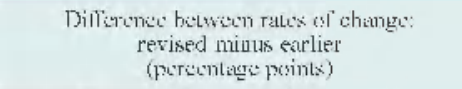 } \\
\hline & & 2011 & 20102 & 20103 & 2014 & 20015 & 2011 & 2012 & 2033 & $2 ? 1194$ & 20115 \\
\hline 'Tutal industry ....... & $\cdots$ & -5.3 & 2.3 & 1.5 & 4.3 & 3.1 & -.2 & .8 & 3 & .0 & .2 \\
\hline 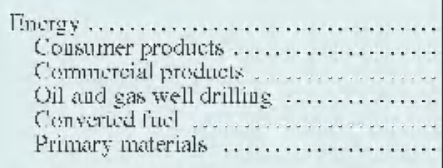 & $\begin{array}{l}\cdots \\
\cdots \\
\cdots \\
\cdots \\
\cdots\end{array}$ & $\begin{array}{r}-3.3 \\
-5.3 \\
-1.4 \\
-7.8 \\
-8.0 \\
i\end{array}$ & $\begin{array}{r}2.8 \\
9.5 \\
4.5 \\
-1.5 .2 \\
4.1 \\
-1.6\end{array}$ & $\begin{array}{r}.5 \\
-1.9 \\
5.1 \\
31.2 \\
.6 \\
-.4\end{array}$ & $\begin{array}{r}.7 \\
1.7 \\
2.4 \\
8.3 \\
1.6 \\
-1 . i 1\end{array}$ & $\begin{array}{r}-2.1 \\
2.4 \\
3.0 \\
11.8 \\
-1.7 \\
-0.5\end{array}$ & $\begin{array}{r}10 \\
-.1 \\
-.2 \\
.3 \\
.1 \\
. j\end{array}$ & $\begin{array}{r}-.2 \\
-.6 \\
-.2 \\
.3 \\
.1 \\
-.1\end{array}$ & $\begin{array}{r}.7 \\
-.5 \\
5.1 \\
.2 \\
.6 \\
.1\end{array}$ & $\begin{array}{r}.2 \\
-.7 \\
-.10 \\
-.4 \\
-.1 \\
1.6\end{array}$ & $\begin{array}{r}-.1 \\
3.1 \\
1.3 \\
1.2 \\
-1.3 \\
-.6\end{array}$ \\
\hline 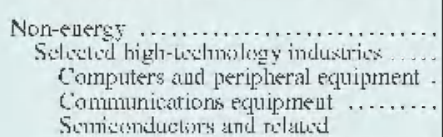 & $\begin{array}{l}\cdots \\
3341 \\
33+2\end{array}$ & $\begin{array}{r}-5.7 \\
-9.8 \\
-3.7 \\
-27.4\end{array}$ & $\begin{array}{r}3.2 \\
4.8 \\
-3.6 \\
-236\end{array}$ & $\begin{array}{r}1.7 \\
21.1 \\
5.8 \\
9.9\end{array}$ & $\begin{array}{r}5.1 \\
18.4 \\
4.6 \\
32.3\end{array}$ & $\begin{array}{r}4.4 \\
26.1 \\
11.3 \\
35.7\end{array}$ & $\begin{array}{r}-. \frac{3}{3} \\
.9 \\
-.9\end{array}$ & $\begin{array}{r}1.0 \\
-3.3 \\
-3.5 \\
-8.3\end{array}$ & $\begin{array}{r}.2 \\
2.4 \\
-16.0 \\
-126\end{array}$ & $\begin{array}{r}.0 \\
-.3 \\
-3.3 \\
12.8\end{array}$ & $\begin{array}{r}.7 \\
1.0 \\
-1.2 \\
3.4\end{array}$ \\
\hline 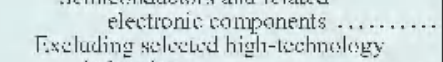 & $33+412-9$ & -.6 & 26 ii & 34.1 & 21.4 & $3 i 1.7$ & -2.3 & 8 & 17.9 & -8.5 & -1.15 \\
\hline 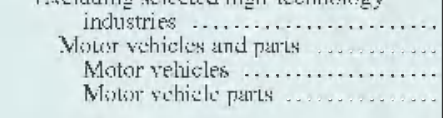 & $\begin{array}{l}33613 \\
3361 \\
3362\end{array}$ & $\begin{array}{r}-5.7 \\
-1.8 \\
3.4 \\
-4.0\end{array}$ & $\begin{array}{r}1.9 \\
12.2 \\
14.4 \\
10.2\end{array}$ & $\begin{array}{r}.5 \\
4.7 \\
101.4 \\
-1.5\end{array}$ & $\begin{array}{l}4.2 \\
2.6 \\
1.6 \\
2.2\end{array}$ & $\begin{array}{l}3.0 \\
2.3 \\
-.2 \\
3.3\end{array}$ & $\begin{array}{r}-.3 \\
.2 \\
-.1 \\
1.0\end{array}$ & $\begin{array}{l}1.3 \\
1.0 \\
3.3 \\
-.5\end{array}$ & $\begin{array}{r}.1 \\
-.1 \\
3.3 \\
-4.2\end{array}$ & $\begin{array}{r}.0 \\
-.3 \\
-.8 \\
.5\end{array}$ & $\begin{array}{l}.1 \\
.8 \\
.2 \\
.2\end{array}$ \\
\hline 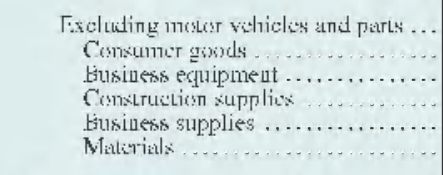 & $\begin{array}{l}\cdots \\
\cdots \\
\cdots \\
\cdots\end{array}$ & $\begin{array}{r}-5.5 \\
-1.5 \\
-11.3 \\
-4.8 \\
-6.4 \\
-7.8\end{array}$ & $\begin{array}{r}9 \\
61 \\
.4 \\
1.4 \\
1.4 \\
1.8\end{array}$ & $\begin{array}{r}.0 \\
.7 \\
.5 \\
1.7 \\
-1.6 \\
-.8\end{array}$ & $\begin{array}{l}4.4 \\
2.3 \\
9.3 \\
4.6 \\
3.3 \\
4.7\end{array}$ & $\begin{array}{r}3.1 \\
2.1 \\
9.5 \\
6.7 \\
2.6 \\
8\end{array}$ & $\begin{array}{r}-3 \\
-1.7 \\
.10 \\
-6 \\
-6\end{array}$ & $\begin{array}{l}1.3 \\
1.2 \\
2.5 \\
1.1 \\
1.6 \\
1.2\end{array}$ & $\begin{array}{r}.1 \\
0 \\
.4 \\
1.1 \\
-.7 \\
.1\end{array}$ & $\begin{array}{r}.0 \\
-1.4 \\
-.3 \\
.7 \\
. \frac{7}{6}\end{array}$ & $\begin{array}{r}.0 \\
-3 \\
-3.4 \\
-.1 \\
.4 \\
.4\end{array}$ \\
\hline 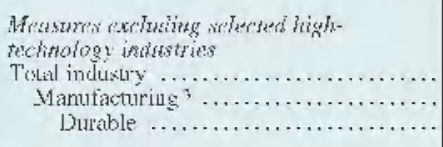 & $\begin{array}{l}\cdots \\
\cdots\end{array}$ & $\begin{array}{l}-4.9 \\
-5.3 \\
-7.2\end{array}$ & $\begin{array}{l}2.1 \\
1.9 \\
3.5\end{array}$ & $\begin{array}{r}.5 \\
.4 \\
1.3\end{array}$ & $\begin{array}{l}3.6 \\
4.2 \\
5.6\end{array}$ & $\begin{array}{l}1.9 \\
2.8 \\
5.5\end{array}$ & $\begin{array}{l}-.2 \\
-.3 \\
-.7\end{array}$ & $\begin{array}{l}1.0 \\
1.3 \\
1.3\end{array}$ & $\begin{array}{l}.2 \\
.11 \\
.5\end{array}$ & $\begin{array}{l}.1 \\
.15 \\
.5\end{array}$ & $\begin{array}{l}0 \\
.0 \\
.3\end{array}$ \\
\hline 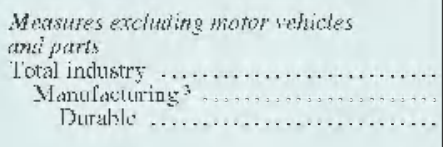 & $\begin{array}{l}\ldots \\
\cdots \\
\cdots\end{array}$ & $\begin{array}{l}-5.5 \\
-5.9 \\
-8.6\end{array}$ & $\begin{array}{l}1.5 \\
1.3 \\
2.2\end{array}$ & $\begin{array}{l}1.3 \\
1.4 \\
3.8\end{array}$ & $\begin{array}{l}4.5 \\
5.4 \\
8.0\end{array}$ & $\begin{array}{l}3.3 \\
4.4 \\
8.9\end{array}$ & $\begin{array}{l}-. .3 \\
-.7 \\
-.7\end{array}$ & $\begin{array}{l}.8 \\
.6\end{array}$ & $\begin{array}{l}.3 \\
.2 \\
.9\end{array}$ & $\begin{array}{l}.1 \\
.1 \\
.7\end{array}$ & $\begin{array}{l}.1 \\
.1 \\
.6\end{array}$ \\
\hline 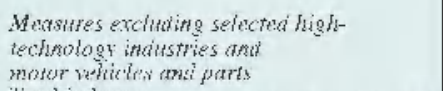 & & & & & & & & & & & \\
\hline $\begin{array}{l}\text { l'otal industry } \ldots \ldots \ldots \ldots \ldots \ldots \ldots \ldots \ldots \\
\text { Yianufikeuring } \\
\end{array}$ & $\cdots$ & -5.1 & $\begin{array}{l}1.3 \\
1.0\end{array}$ & $\frac{1}{0}$ & $\begin{array}{l}3.6 \\
4.4\end{array}$ & $\begin{array}{l}1.9 \\
2.9\end{array}$ & -3 & $\frac{1.6}{1.3}$ & .2 & $\begin{array}{l}.0 \\
.1\end{array}$ & $\begin{aligned} 0 \\
-.1\end{aligned}$ \\
\hline 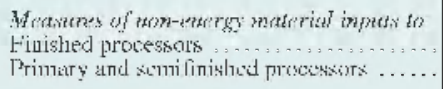 & $\cdots$ & $\begin{array}{l}-8.5 \\
-5.8\end{array}$ & $\begin{array}{l}5.7 \\
3.2\end{array}$ & $\begin{array}{r}3.6 \\
.2\end{array}$ & $\begin{array}{l}7.9 \\
4.3\end{array}$ & $\frac{8.4}{-.5}$ & -.8 & $1 . \frac{3}{5}$ & $\begin{array}{r}1.7 \\
.2\end{array}$ & -.4 & $\begin{array}{l}.8 \\
.7\end{array}$ \\
\hline 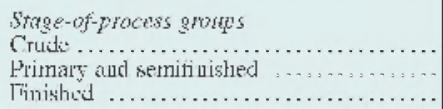 & $\cdots$ & $\begin{array}{l}-2.8 \\
-6.3 \\
-4.5\end{array}$ & $\begin{array}{r}-1.1 \\
4.2 \\
.6\end{array}$ & $\begin{array}{r}-1.7 \\
1.2 \\
2.8\end{array}$ & $\begin{array}{l}1.9 \\
4.4 \\
4.9\end{array}$ & $\begin{array}{r}-8.2 \\
4.4 \\
5.3\end{array}$ & $\begin{array}{r}.2 \\
-.4 \\
.1\end{array}$ & $\begin{array}{r}-.1 \\
.8 \\
1.0\end{array}$ & $\begin{array}{r}-.3 \\
-.4\end{array}$ & $\begin{array}{r}1.8 \\
.1 \\
-.5\end{array}$ & $\begin{array}{r}-1.9 \\
1.2 \\
-.4\end{array}$ \\
\hline
\end{tabular}

Now: Estimates for the fourth quarter of $20 j 55$ are subject to turther revision

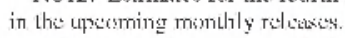

1. Kates of thange are calculated as the percent change in the seasonally

the rates of change are calculated from annualized rates of change between the

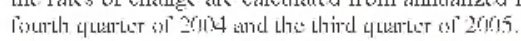

2. North Americuan Tndustry ('lassiliculion Syxtem.

adjusted index from the tourth quarter of the previous year to the fourth guarter

3. Reter to footnote 3 in table A.3. 
A.5. Rates of change for annual industrial production indexes, 2001-05 1

\begin{tabular}{|c|c|c|c|c|c|c|c|c|c|c|}
\hline \multirow[t]{2}{*}{ Tlim } & \multicolumn{5}{|c|}{$\begin{array}{l}\text { Revisud rate of shange } \\
\text { (perceut) }\end{array}$} & \multicolumn{5}{|c|}{ 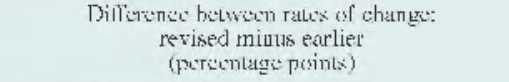 } \\
\hline & 2001 & 2012 & $2010 ;$ & 201014 & 20105 & 2001 & 201012 & 2003 & 2004 & 201015 \\
\hline 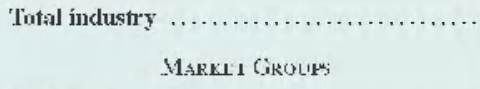 & -3.5 & .1 & .6 & 4. 1. & 3.2 & .0 & .4 & .6 & -.1 & .1 \\
\hline 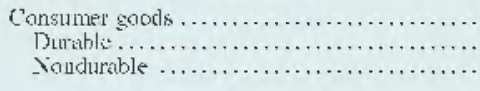 & $\begin{array}{r}-1.1 \\
-4.3 \\
.1\end{array}$ & $\begin{array}{r}2.2 \\
6.3 \\
.3\end{array}$ & $\begin{array}{l}1.01 \\
4.0 \\
-.2\end{array}$ & $\begin{array}{l}3.1 \\
2.8 \\
1.8\end{array}$ & $\begin{array}{l}3.1 \\
1.5 \\
3.2\end{array}$ & i) & $\begin{array}{r}8 \\
9 \\
.7\end{array}$ & $\begin{array}{r}.8 \\
1.5 \\
.4\end{array}$ & $\begin{array}{l}-.6 \\
-.3 \\
-.8\end{array}$ & $\begin{array}{r}-.4 \\
.2 \\
-.6\end{array}$ \\
\hline 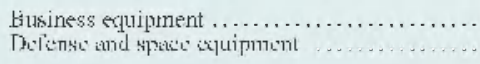 & $\begin{array}{r}-7.6 \\
8.6\end{array}$ & $\begin{array}{r}-7.8 \\
-.1\end{array}$ & $\underset{50}{50}$ & 7.8 & 10.6 & $-\frac{1}{3}$ & $-1 . \frac{1}{2}$ & -1.3 & $\begin{array}{l}-.1 \\
3.1\end{array}$ &.$\frac{7}{1.1}$ \\
\hline $\begin{array}{l}\text { Comstructiom supplies } \ldots \ldots \ldots \ldots \ldots \ldots \ldots \ldots \ldots \ldots \\
\text { biusiness supplies } \ldots \ldots \ldots \ldots \ldots \ldots \ldots\end{array}$ & $\begin{array}{l}-4.5 \\
-4.6\end{array}$ & $-\frac{2}{2}$ & -9 & $\begin{array}{l}5.5 \\
3.7\end{array}$ & $\begin{array}{l}4.0 \\
3.5\end{array}$ & $\begin{array}{l}-1 \\
i\end{array}$ & $\begin{array}{r}.7 \\
1 . i\end{array}$ & $\begin{array}{l}1.4 \\
1.1\end{array}$ & $\begin{array}{r}4 \\
-1.3\end{array}$ & .4 \\
\hline 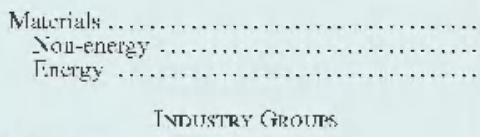 & $\begin{array}{l}-4.5 \\
-5.6 \\
-1.1\end{array}$ & $\begin{array}{r}1.0 \\
1.4 \\
0\end{array}$ & $\begin{array}{r}.4 \\
.6 \\
-.4\end{array}$ & $\begin{array}{r}4.2 \\
5.8 \\
.1\end{array}$ & $\begin{array}{r}2.0 \\
3.5 \\
-1.7\end{array}$ & $\begin{array}{l}0 \\
0 \\
0\end{array}$ & $\begin{array}{l}.1 \\
.1 \\
.1\end{array}$ & $\frac{9}{3}$ & $\begin{array}{l}.5 \\
.6 \\
4\end{array}$ & $\begin{array}{r}. .3 \\
-.2 \\
-.2\end{array}$ \\
\hline 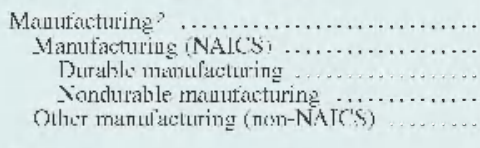 & $\begin{array}{l}-4.2 \\
-4.1 \\
-4.8 \\
-3.2 \\
-5.9\end{array}$ & $\begin{array}{r}.1 \\
.3 \\
-.2 \\
1.01 \\
-3.01\end{array}$ & $\begin{array}{r}.5 \\
.7 \\
2.3 \\
-1.1 \\
-3.1\end{array}$ & $\begin{array}{l}4.8 \\
5.0 \\
7.3 \\
3.3 \\
1.8\end{array}$ & $\begin{array}{r}3.9 \\
3.9 \\
6.4 \\
-7 \\
3.0\end{array}$ & $\begin{array}{r}. i 1 \\
.1 \\
.1 \\
-i 1 \\
-.2\end{array}$ & $\begin{array}{r}5 \\
.4 \\
6 \\
8 \\
2 \\
201\end{array}$ & $\begin{array}{r}.6 \\
.7 \\
1.0 \\
-2.0 \\
-2.0\end{array}$ & $\begin{array}{r}.0 \\
.3 \\
.3 \\
-2.4 \\
\end{array}$ & $\begin{array}{r}.1 \\
.3 \\
.7 \\
-.6 \\
-.4\end{array}$ \\
\hline $\begin{array}{l}\text { Mining } \ldots \ldots \ldots \ldots \ldots \ldots \ldots \ldots \ldots \ldots \ldots \ldots \ldots \\
\text { IItilities } \ldots \ldots \ldots \ldots \ldots \ldots \ldots \ldots \ldots \ldots \ldots \ldots \ldots \ldots\end{array}$ & -5 & $\begin{array}{r}-4.3 \\
3.1\end{array}$ & -.2 & -.2 & $\begin{array}{r}-2.19 \\
3.6\end{array}$ & 0 & $\begin{array}{r}-1 \\
. i\end{array}$ & $\begin{array}{l}.2 \\
1.6\end{array}$ & $\begin{array}{r}7 \\
-1.4\end{array}$ & -.4 \\
\hline
\end{tabular}

A.6. Rates of change in capacity, by industry groups, 2001-051

\begin{tabular}{|c|c|c|c|c|c|c|c|c|c|c|}
\hline \multirow[t]{2}{*}{ Item } & \multicolumn{5}{|c|}{$\begin{array}{l}\text { Revised rate of chauge } \\
\text { (percintI }\end{array}$} & \multicolumn{5}{|c|}{$\begin{array}{c}\text { Difterence between rates of chauge: } \\
\text { ruvisud minus varlicr } \\
\text { ipercentage points i }\end{array}$} \\
\hline & $20 j j 1$ & 36012 & $2 i 1133$ & $30 i 14$ & 200105 & $20 i j 1$ & zilitz & $26 j i 3$ & $20 i 4$ & 201015 \\
\hline Total indusiry ........ & 2.9 & .7 & -.2 & .6 & 1.6 & .2 & .3 & . & -.5 & .4 \\
\hline Manulacturing ${ }^{2}$ ? & 28 & 4 & -.1 & .5 & 2.1 &.$^{3}$ & $\therefore$ & 0 & -6 & .7 \\
\hline Manufacturiug iNALCSi & 3.1 & .5 & .1 & .5 & 2.2 & .3 & .4 & (i) & -.7 & .7 \\
\hline Duralsle mathufacturing & 5.1 & 1.1 & 1.2 & 1.4 & 40 & $\hat{2}$ & .5 & i) & -8 & 10 \\
\hline Ciondurable mautuasturing & .5 & -.3 & -1.1 & -.7 & -.2 & 4 & .3 & .2 & -.5 & .3 \\
\hline Other manulacturing (nem-NATCS) ......... & -1.1 & -2.7 & -30 & 4 & 5 & $\hat{2}$ & -.2 & -1 & 3 & .2 \\
\hline 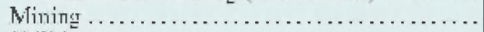 & 2.1 & -1.3 & -1.0 & -6 & -6 & 6 & -.7 & 7 & -3 & 1 \\
\hline 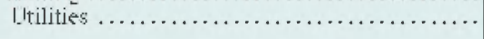 & 3.9 & 4.5 & 3.1 & 26 & il & i) & .6) & .1 & .7 & -1.2 \\
\hline Selected high-techuology industries . & 27.8 & 9.5 & 8.01 & 6.8 & 201.8 & .3 & 1.5 & -.4 & -6.6 & 5.) \\
\hline high-technology industries ${ }^{2}$. & 8 & -.2 & -.5 & .1 & 6 & .3 & .2 & .1 & . & .3 \\
\hline Stage-of-process groms & & & & & & & & & & \\
\hline 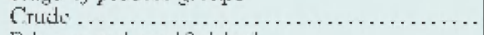 & 1.5 & -10 & -2.1 & -1.1 & -9 & 6 &.- .3 & .2 & -9 & -.2 \\
\hline Phimary and somifinished . ................. & 3.4 & 9 & -.1 & $\therefore$ & 2.5 & .5 & .2 & .1 & -1.1 & .7 \\
\hline Finished $\ldots \ldots \ldots \ldots \ldots \ldots \ldots \ldots \ldots \ldots \ldots$ & 2.3 & 6 & 6 & .8 & 1.2 & -.1 & .4 & . & 5 & .3 \\
\hline
\end{tabular}

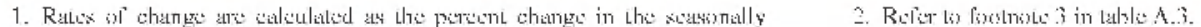
adjusted incles from the fourth quarter of the previous year to the fourth quarter of lis year specilied in the column heading. 
A.7. Capacity utilization rates, by industry groups, 1972-2005

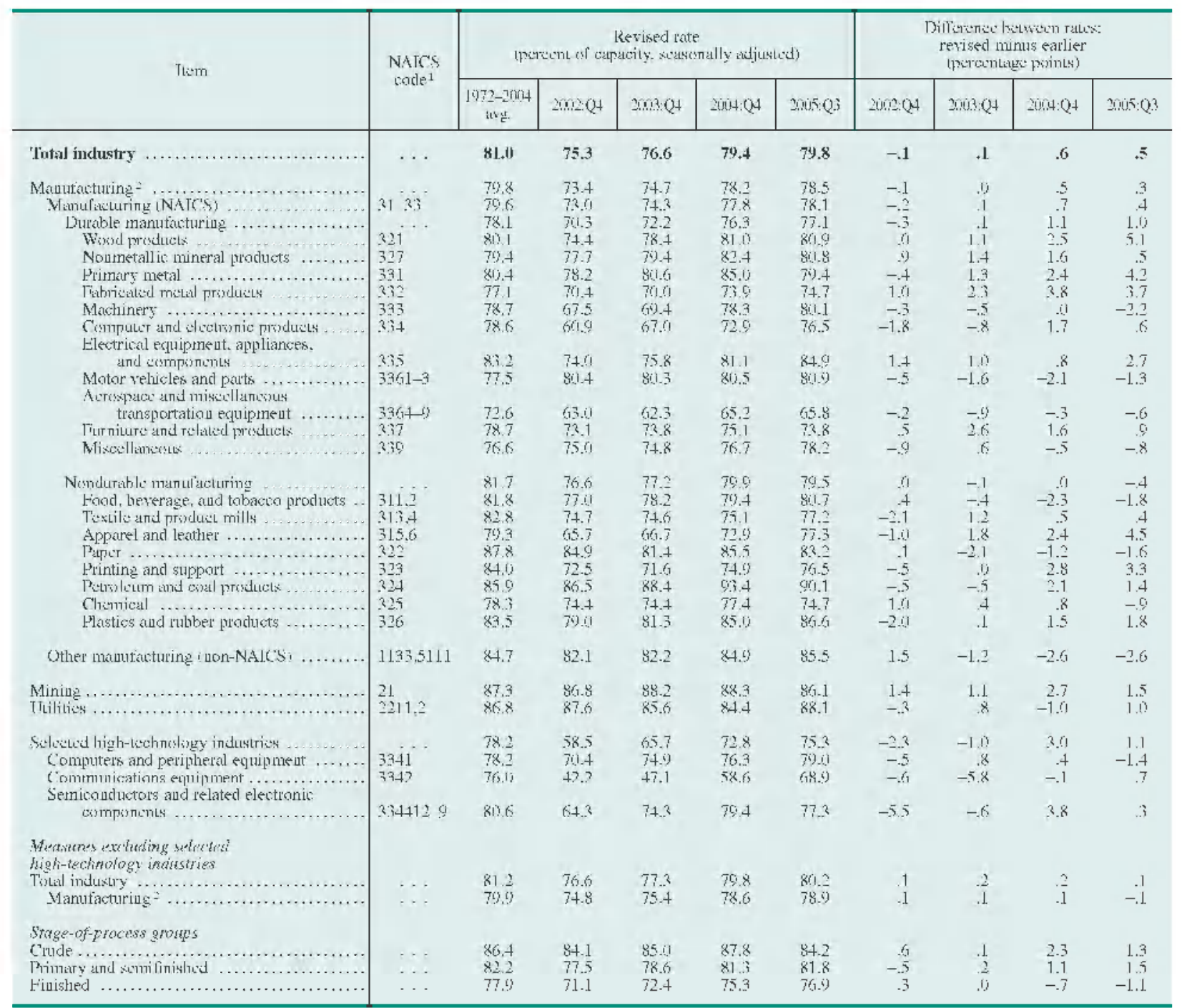

1. Virth American Tndusity Classification Systim.

... .ou applicable

2. Refer to fontnote 3 in table A.3. 
A.8. Annual proportion in industrial production, by market groups and industry groups, 1997-2005

\begin{tabular}{|c|c|c|c|c|c|c|c|c|c|c|}
\hline Item & $\begin{array}{l}\text { NATCS } \\
\text { rade }^{1}\end{array}$ & 1997 & 1958 & 1959 & 3iliiij & $20 j i j 1$ & ziliti & $200 j 3$ & 3iiil4 & 20105 \\
\hline 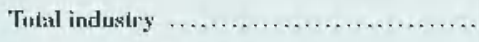 & $\cdots$ & 100.0 & 100.0 & 100.0 & 100.0 & 100.0 & 100.0 & 100.0 & 100.0 & 100.0 \\
\hline \multicolumn{11}{|l|}{ WARKFT GROTIS } \\
\hline Fiual products aud nouiudustrial supplies ...... & $\ldots$ & 56.9 & 58.1 & 57.6 & 57.6 & 5i).1. & 5901 & 58.6 & 57.8 & 57.6 \\
\hline Cousumer zonds ........................ & $\cdots$ & 27.6 & 28.0 & 28,3 & 28.5 & 3011 & 31.0 & 31.7 & 30.2 & 29.7 \\
\hline Duralsh: $\ldots \ldots \ldots \ldots \ldots \ldots \ldots \ldots$ & $\ldots$ & 7.9 & 79 & 810 & 79 & 8.1 & 8.9 & 910 & 8.7 & 8.3 \\
\hline Automotive products $. . . \ldots \ldots \ldots \ldots . . .$. & $\cdots$ & 3.7 & 3.7 & 3.9 & 3.7 & 4.0 & 4.7 & 4.9 & 4.7 & 4.6 \\
\hline Home clostrentes & $\cdots$ & 4 & 4 & 4 & 4 & 4 &.$^{2}$ & 3 & 3 & .2 \\
\hline Appliauces, turniture, arpeting . ...... & $\ldots$ & 1.4 & 1.4 & 1.4 & 1.4 & 1.4 & 1.5 & 1.4 & 1.4 & 1.4 \\
\hline Mícollimesus gordx. . . . . . . . . . . & $\ldots$ & 2.4 & 24 & 2.4 & 2.4 & 2.3 & 2.4 & 2.3 & 2.3 & 2.2 \\
\hline Viondurable...$\ldots \ldots \ldots \ldots \ldots \ldots \ldots$ & $\ldots$ & 19.7 & $31 j .1$ & $3 i 1.3$ & 21.7 & 32.0 & 23.1 & 32.1 & 21.6 & 21.3 \\
\hline Non-chergy ............... & $\ldots$ & 16.3 & 169 & 16.7 & 169 & 18.1 & 18.2 & 180 & 17.4 & 169 \\
\hline roods aud tobacco ............... & $\cdots$ & 8.7 & 9.3 & 9.1 & 9.3 & 1010 & 9.8 & 9.8 & 9.5 & 9.1 \\
\hline Clishling ......................... & $\ldots$ & 1.6 & 1.5 & 1.3 & 1.2 & 1.1 & 1.0 & 5 & .8 & 7 \\
\hline Chemical products & $\ldots$ & 3.7 & 3.8 & 3.8 & 39 & 4.5 & 49 & 4.5 & 4.8 & 4.7 \\
\hline Paper products ................... & $\ldots$ & 1.8 & 1.9 & 1.9 & 1.9 & $3.1 j$ & 2.1 & 1.9 & 1.i) & 1.5 \\
\hline 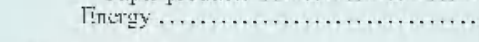 & $\cdots$ & 3.4 & 3.2 & 3.5 & 3.7 & 38 & 39 & 4.1 & 4.2 & 4.4 \\
\hline 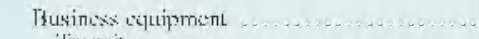 & . & 11.8 & 12,3 & 119 & 11.7 & 11,2 & 10,3 & 90 & 100 & 10.1 \\
\hline 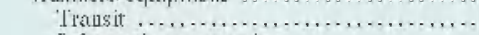 & $\cdots$ & 2.1 & 3.5 & 1.3 & $2 i 1$ & 3.5 & 1.) & 1.8 & 1.9 & 2.0 \\
\hline Tnfirmation prisessinge & $\ldots$ & 4.9 & $41 ?$ & 4.1 & 4.1 & 38 & 3.1 & 2.9 & 2.7 & 28 \\
\hline Industrial aud other $\ldots \ldots \ldots \ldots \ldots \ldots \ldots$ & $\ldots$ & 5.8 & 5.8 & 5.5 & 5.6 & 5.4 & 5.3 & 5.7 & 5.4 & 5.3 \\
\hline 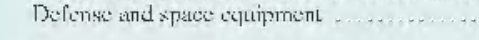 & $\cdots$ & 1.9 & 19 & 18 & 1.5 & 18 & 1.8 & 19 & 1.9 & 2.1 \\
\hline Coustruction supplies. & . & 4.2 & 4.3 & 4.3 & 4.3 & 4.3 & 4.3 & 4.3 & 4.4 & 4.5 \\
\hline Thusiness stupplies & $\cdots$ & 11.1 & 11.1 & 111 & 11.2 & 11.2 & 11.2 & 11.1 & 10.8 & 10.6 \\
\hline Naurials. & . . & 4.3 .1 & 419 & 424 & 42.4 & 40.9 & 41.0 & 41.4 & 42.2 & 42.4 \\
\hline Visu-energy . ......................... & $\ldots$ & 33.8 & 33.3 & 33.1 & 31.3 & 30,9 & $31 j .7$ & 301.0 & 30.2 & 39).4 \\
\hline 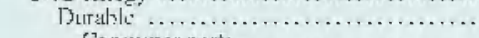 & $\ldots$ & 21.7 & 21.5 & 21.4 & 209 & 196 & 19.1 & 18.7 & 190 & 18.8 \\
\hline Consumer pouts .................... & $\cdots$ & 4.2 & 4.7 & 4.4 & 41 & 3.8 & $4 i$ & 3.8 & 3.7 & 3.5 \\
\hline TiquipmenL parts .... . . o . . . . . & $\ldots$ & 8.2 & 82 & 8.1 & 8.2 & 73 & 6.7 & 66 & 6.7 & 6.7 \\
\hline Other $\ldots \ldots \ldots \ldots \ldots \ldots \ldots \ldots \ldots \ldots$ & $\ldots$ & 9.2 & 9.1 & 8.9 & 8.6 & 8.4 & 8.4 & 8.4 & 8.7 & 8.5 \\
\hline Vondurable...$\ldots \ldots \ldots \ldots \ldots \ldots \ldots \ldots$ & $\cdots$ & 12.1 & 11.8 & 11.7 & 11.4 & 1.1 .3 & 11.6 & 11.3 & 11.2 & 10.7 \\
\hline 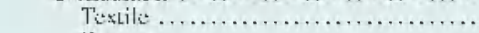 & . . & 1.1 & $1.1 ?$ & 110 & 9 & 8 & .8 & 8 & .7 & 6 \\
\hline Paper ........................... & $\ldots$ & 2.9 & 3.8 & 3.9 & 2.8 & 3.8 & 2.7 & 2.5 & 3.4 & 2.3 \\
\hline 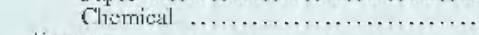 & . & 4.9 & 4.6 & 4.5 & 4.3 & 42 & 4.5 & 4.5 & 4.7 & 4.4 \\
\hline 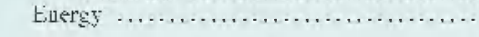 & $\cdots$ & 9.3 & 8.6 & 9.1 & 10.1 & $10.1)$ & 10.3 & 11.4 & 12.0 & 13.0 \\
\hline \multicolumn{11}{|l|}{ IVDLISIRY GRotes; } \\
\hline Manul'acturing & & 85.7 & 86.5 & 858 & 84.5 & $8+1$ & 8399 & 82.6 & 8201 & 80.8 \\
\hline Manufacturiug NAlcsi $\ldots \ldots \ldots \ldots \ldots \ldots$ & $31-33$ & 81.3 & 81.8 & 81.0 & 70.7 & 79.2 & $70) 1$ & 77.9 & 77.5 & 76.4 \\
\hline Duralsk mainufacturing . ............... & & 45.5 & 47.1 & 46.7 & 4.6 .6 & $44 ;$ & 4.3 .6 & 420 & 43.1 & 429 \\
\hline Wood products .................... & 321 & 1.5 & 1.5 & 1.6 & 1.4 & 1.4 & 1.5 & 1.5 & 1.6 & 1.5 \\
\hline Nemmetall lic mineral products . . ....... & 327 & 2.2 & 2.3 & 2.3 & 2.2 & 2.3 & 2.3 & 2.2 & 2.3 & 2.3 \\
\hline Primary metal .......................... & 331 & 3.1 & 3.9 & 3.8 & 3.5 & 2.3 & 3.3 & 2.3 & 360 & 2.4 \\
\hline Tiabricualied mistial prisducts ............ & 332 & 601 & 6.1 & $61)$ & 601 & 50 & 5.7 & 5.6 & 5.7 & 58 \\
\hline Machinery ....................... & 333 & 6.3 & 6.3 & 5.9 & 6.0 & 5.7 & 5.3 & 5.1 & 5.4 & 5.3 \\
\hline Computer and electrouis products ...... & 334 & 10.4 & 10,2 & 10,3 & 103 & 9.3 & 80 & 7.8 & 7.7 & 7.9) \\
\hline 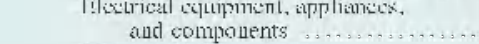 & 335 & 2.6 & 3.6 & 3.5 & 2.5 & 3.4 & 2.2 & 2.1 & 3.1 & 2.1 \\
\hline Molis vehicles and parts ............ & 33613 & 6.7 & 6.6 & $7.1)$ & 66 & 65 & 7.4 & 7.5 & $\overline{7} .3$ & 7.1 \\
\hline Aerospace and miscellaneous & & & & & & & & & & \\
\hline Lranspertiatlisn cijuipment .. & 33649 & 3.4 & 4.1 & 38 & $3 . .3$ & 3.8 & 3.6 & 3.5 & 3.5 & 3.7 \\
\hline Firuiture and related produsts $\ldots . .$. . . & 337 & 1.6 & 1.7 & 1.7 & 1.7 & 1.7 & 1.8 & 1.8 & 1.7 & 1.6 \\
\hline 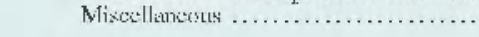 & 339 & 2.8 & 28 & 28 & 29 & 3.1 & $3 . .2$ & 3.3 & 3.2 & 3.2 \\
\hline Timdurahle menulucturing $\ldots \ldots \ldots \ldots$ & & 34.7 & 347 & 34.4 & 34.1 & 350 & 3.5 & 350 & 34.4 & 33.5 \\
\hline 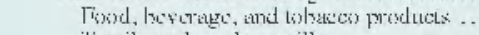 & 311,2 & 10.1 & 106 & 10.4 & 10.7 & 11.4 & 11.4 & 11.4 & 11.0 & 10.7 \\
\hline lestile and product mills .............. & 313.4 & 1.7 & 1.6 & 1.5 & 1.4 & 1.3 & 1.4 & 1.3 & 1.2 & 1.1 \\
\hline Apparal and lealier $\ldots \ldots \ldots \ldots \ldots \ldots$ & $31.5,6$ & 1.8 & 1.6 & 1.4 & 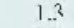 & 1.2 & 1.0 & 9 & .8 & .7 \\
\hline Paper $\ldots \ldots \ldots \ldots \ldots \ldots \ldots \ldots \ldots \ldots \ldots$ & 322 & 3.2 & 3.2 & 3.2 & 3.2 & 3.1 & 3.1 & 2.3 & 2.8 & 2.7 \\
\hline Printing and suppomt ................ & 323 & 2.7 & 26 & 2.6 & 2.6 & 2.6 & 2.4 & 2.3 & 2.1 & 20 \\
\hline Eetroleum and coal products ........... & 324 & 1.6 & 1.5 & 1.7 & 1.i) & 1.7 & 1.7 & 2.0 & 3.3 & 2.5 \\
\hline Chimical $\ldots \ldots \ldots \ldots \ldots \ldots \ldots \ldots$ & 325 & 10.1 & 90 & 96 & 9.4 & 98 & 10.6 & 10.6 & 10.5 & 10.2 \\
\hline Hastics and rubber products .......... & 326 & 3.7 & 3.7 & 3.8 & 3.7 & 3.7 & 3.8 & 3.7 & 3.6 & 3.6 \\
\hline Other mautuaturing i uon-NALC'si & 1133.5111 & 4.4 & 4.7 & 4.8 & 4.8 & 4.9 & 4.8 & 4.7 & 4.5 & 4.4 \\
\hline Mining .......... & 21 & 5.4 & 4.8 & 5.5 & 6.5 & 64 & 6.4 & 7.5 & 8.5 & 98 \\
\hline Itilities ... & 2311,2 & 8.9 & 8.7 & 8.6 & 90 & 9.5 & 9.7 & (9.) & 9.5 & 9.5 \\
\hline 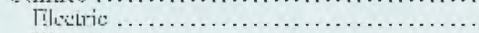 & 2211 & 7.7 & 7.5 & 7.4 & 7.6 & 8.1 & 8.2 & 8.3 & 7.9 & 7.8 \\
\hline 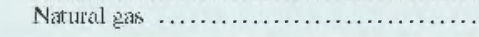 & 2212 & 1.3 & 1.2 & 1.2 & 1.4 & 1.4 & 1.4 & 1.6 & 1.6 & 1.7 \\
\hline
\end{tabular}

NoTE: The IP proportion data are estimates of the industries" relative contributions to the overall IP change between the reference year and the following year. For example, a 1 percent increase in durable goods manufacturing between 2005 and 2006 would account for a 0.429 percent increase in total IP.
1. Nerrlh Americuan Tndustry C'lussilicualion System.

2. Reter to footnote 3 in table A.3.

... Viot applicable. 